\title{
IMAGEN, MODERNIDAD Y TIEMPO-NACIÓN EN EL PAPEL PERIÓDICO ILUSTRADO (1881-1888)
}

\author{
POR \\ WILSON JiMÉNEZ HERNÁNDEZ \\ Universidad de Bogotá
}

La amplia gama de transformaciones del largo siglo XIX latinoamericano es uno de los rasgos más interesantes para el abordaje histórico enfocado en comprender nuestro ingreso en la modernidad. Una modernidad contradictoria, particular, diferente, compleja. Una modernidad confusa en la que el problema de la construcción del Estado-nación fue uno de los ejes principales de transformaciones políticas, sociales y culturales. Transformaciones que relacionaron directamente diversos fenómenos en los que las élites intelectuales y políticas, así como también los artesanos, los artistas y las comunidades indígenas y negras fueron de una u otra forma partícipes. Estas dos últimas, fundamentalmente, como objeto de imposición de subjetividades, discursos raciales y prácticas de diferenciación.

En la configuración de esta modernidad compleja, las imágenes visuales participaron en ámbitos de transformaciones tan diversas como la ampliación de la opinión pública, la extensión y resignificación del campo de la estética, la construcción de una nueva lectura del tiempo de la nación, el afianzamiento del principio de distinción y la imposición de subjetividades. Estos ámbitos fueron estructurados mediante el uso de diversas estrategias en las que la prensa se destacó como una de las herramientas más apropiadas para "unificar intereses, el punto de partida para construir hegemonías políticas y culturales; [...] medio fundamental para difundir ideologías y familiarizar a los ciudadanos con proyectos de organización social" (Loaiza 159). Su capacidad de generación y difusión de significados en representaciones verbales y visuales, fue el mayor potencial del que impresores, grabadores, políticos y artistas hicieron uso para lograr desarrollar los retos y transformaciones requeridos en el proceso de articulación y consolidación de la modernidad decimonónica.

En Colombia este proceso fue experimentado con más firmeza durante la segunda mitad del siglo XIX, especialmente en el contexto de transición política y cultural que hacia la década de los años ochenta constituyó el declive del Radicalismo liberal y el afianzamiento de la Regeneración conservadora, el cual definió la estructura social y política que caracterizó gran parte del siglo XX. 
La Regeneración fue un proyecto de reorganización estatal que enfrentó las paradojas de una modernidad compleja y aparentemente contradictoria, al contrastar una idea pragmática y positiva de orden y progreso con una idea de orden social orgánico y estratificado en el que la religión católica se constituyó en el fundamento de la ética y la política. ${ }^{1}$ Para su consecución, la construcción del Estado-nación promulgado por la Regeneración giró en torno a tres ejes: la centralización política y administrativa para solucionar el "caos" generado por el federalismo; el control del sistema productivo exportador soportado en la economía cafetera y la unidad monetaria; y la cohesión social nacional mediante parámetros formadores de identidad que integraron el confesionalismo católico con una idea de herencia española y la tradición como garante de continuidad y potencial futuro de la nación.

En ese momento clave de reconfiguración del Estado-nación colombiano, el periódico de mayor impacto y relevancia fue el Papel Periódico Ilustrado. La importancia de esta empresa editorial, en términos artísticos, culturales y comunicativos, radicó en que fue la primera publicación periódica en el país que hizo uso masivo y sistemático de imágenes visuales producto de grabados en madera y fotograbados, las cuales, acompañadas de textos elaborados por un importante número de los principales intelectuales y políticos del momento, difundieron, construyeron, afianzaron e incluso replantearon varias de las ideas y lecturas que, sobre diversos fenómenos sociales e históricos relacionados con el pasado, el presente y el futuro de la nación, configuraron la opinión pública colombiana de la segunda mitad del siglo XIX.

Por varias de sus características, algunas de las cuales referenciaremos aquí, se puede afirmar que el Papel Periódico Ilustrado es el mejor ejemplo del papel que cumplió la prensa periódica decimonónica en la construcción del Estado-Nación colombiano, de la forma en que las élites políticas e intelectuales respondieron a la necesidad de producir representaciones simbólicas y formaciones discursivas para la transformación y afianzamiento de una comunidad política y cultural legítima, viable y gobernable, pero sobre todo es una valiosa muestra del inmenso poder epistemológico de la imagen para la representación de ideas y conceptos que vinculan la comprensión de una realidad cognoscitiva con la institucionalización de prácticas políticas, así como también de las constantes desviaciones e influencias que imagen y texto recíprocamente ejercen entre sí para la producción de sentido.

Teniendo en cuenta estos puntos, analizaremos el proceso mediante el cual el Papel Periódico Ilustrado articuló imagen, modernidad y nación, para responder a las transformaciones de la opinión pública, el campo de la estética, la formación de una

Para una caracterización de la Regeneración ver: Múnera, "El Estado en la Regeneración” y Palacios, "La Regeneración ante el espejo liberal y su importancia en el siglo XX".

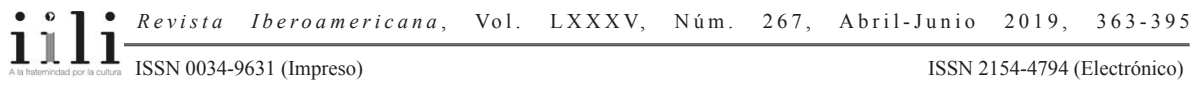


idea de tiempo de nación, la instauración de un principio de distinción y la imposición de subjetividades.

\section{Prensa E imAGen EN LA CONSTRUCCiÓn DEL EstAdO-NACiÓN}

En Colombia, a partir de la década de 1850, y más específicamente con la Ley de Libertad Absoluta de Prensa sancionada el 17 de Mayo de 1851, la producción y distribución de impresos posibilitó vincular importantes avances tecnológicos con el mundo de las artes gráficas. Vínculo que rápidamente se reflejó en la proliferación de talleres de impresión, el surgimiento de un importante número de publicaciones ilustradas y la amplia difusión de imágenes, fortaleciendo una opinión pública polisémica y marcando una nueva etapa en la construcción del proyecto de nación.

Estos diversos elementos, característicos de un capitalismo impreso, en el que el auge de la actividad editorial configuró un campo unificado de intercambios y comunicaciones (Anderson 62-72), estuvieron acompañados de prácticas de lectura pública y de observación de imágenes, que ampliaron el espacio lingüístico y la cultura visual del público receptor. Las diferentes prácticas de lectura y observación que potencializaron las publicaciones ilustradas fortalecieron el campo de producción e intercambio de ideas relacionadas con el lenguaje político y cultural, la estructuración de un campo institucional relacionado con el mundo de la imagen y el afianzamiento de proyectos de organización social. Todos estos hechos generaron una significativa transformación de la naturaleza de la visualidad que implicó un cambio en la forma de relacionarse con las imágenes, un cambio en la experiencia del observador. Experiencia que también se transformó con la reformulación de los conceptos que requería la construcción del proyecto de nación, no sólo en el ámbito político, sino también en el cultural, social y económico.

En el contexto de transformaciones propias de la construcción y afianzamiento del proyecto de Estado-nación, la prensa contó con una variedad de expresiones que dependieron de su objetivo y el tipo de información a divulgar. Periódicos que con muchas vicisitudes podían ser diarios, semanarios, quincenarios o mensuarios, cumplieron funciones de carácter oficial, doctrinario, eleccionario y literario o cultural (Posada 157).

En Bogotá, la ciudad capital, periódicos literarios y culturales como ElNeogranadino (1848-1857), El Zipa (1877-1881), El Mosaico (1858-1872) y el Papel Periódico Ilustrado (1881-1887), por nombrar algunos de los principales, participaron profusamente en la divulgación de una cultura letrada y la estructuración de una subjetividad acorde con una idea de república. ${ }^{2}$ Estas publicaciones ampliaron su radio de difusión mediante

2 Durante el período, la ciudad con mayor número de imprentas y de periódicos fue Bogotá, y después de

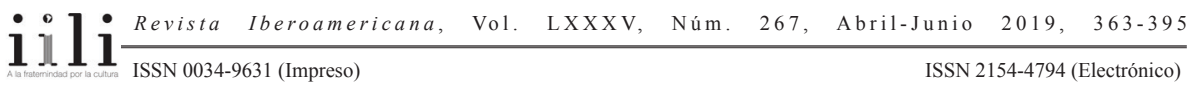


estrategias de mercadeo que estuvieron dirigidas principalmente a aumentar el número de suscripciones e incluyeron una interesante variabilidad temática en el cuerpo del periódico o en anexos.

El primer periódico que hizo uso amplio de la distribución de anexos fue $E l$ Neogranadino, el cual divulgó novelas por entregas, poemarios, partituras y retratos de héroes y próceres. El Zipa, por su parte, ofreció a los suscriptores "un mosaico con los retratos de sus principales colaboradores -entre ellos, José M. Marroquín, Rafael Pombo y José María Samper-" (Posada 155); mientras que El Mosaico, caracterizado por ser el árbitro de la producción literaria y el núcleo de sociabilidades desde el que se estableció la Academia Colombiana de la Lengua, promocionó reproducciones litográficas de personajes de la Nueva Granada, en el catálogo de libros que vendía en su imprenta.

El Papel Periódico Ilustrado, la publicación dirigida por Alberto Urdaneta y editada entre el 6 de agosto de 1881 y el 29 de mayo de 1888, reprodujo un total de 604 grabados en sus 116 números, incluyendo los interiores de cada sección y los principales de portada. Para este periódico, Alberto Urdaneta, una de las personalidades intelectuales más importantes de la segunda mitad del siglo XIX en Colombia, cuya labor estuvo relacionada con creación de periódicos, publicación de libros y organización de exposiciones, se hizo acompañar del grabador español Antonio Rodríguez, colaborador en París del periódico Le Monde Illustré. Rodríguez grabó en el Papel Periódico Ilustrado más de doscientas treinta planchas de diferentes tamaños. A partir de 1889, y hasta 1892, fue uno de los principales grabadores de la publicación Colombia Ilustrada, dirigida por José T. Gaibrois, uno de los colaboradores de Urdaneta, surgida con el objetivo de darle continuidad al proyecto del Papel Periódico Ilustrado. Luego, en 1890, fundó en compañía de Antonio Narváez, el periódico Repertorio Ilustrado, del que solo se publicaron siete números, y en 1895 fue nombrado secretario de la Escuela de Bellas Artes de Bogotá.

El Papel Periódico Ilustrado presentó grabados en todas sus secciones: historia, ciencias, tipos, vistas y otros, crónicas, bellas artes, agricultura, lecturas (novelas cortas y artículos de costumbres), crónica interior y contemporáneos (literatura), aunque no mantuvo la uniformidad en cada edición. Temáticamente la principal sección fue la de Historia. El grabado de la portada siempre se articuló con el texto correspondiente a esta sección, el cual se caracterizó por su estilo biográfico. El vínculo entre imagen y biografía posibilitó la promoción de un panteón cívico acorde a una idea de héroe, modelo de virtudes y valores, de gran potencial estratégico para la formación del ciudadano miembro de la comunidad política y partícipe del fortalecimiento de la

esta, Medellín, Popayán, Cartagena, Santa Marta y Barranquilla (Castaño 54-62); (Jiménez Hernández 115-38).

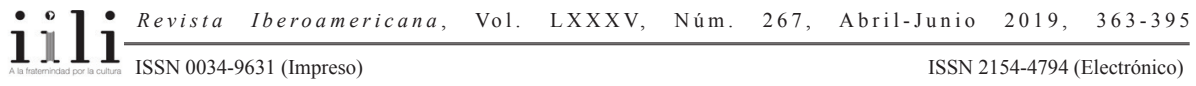


República. La importancia de vincular imagen y texto para la construcción de nación desde el periódico se puede evidenciar en el objetivo establecido por Alberto Urdaneta:

En esta sección publicaremos los estudios relacionados con la historia patria. Cada número llevará en la primera página el retrato de uno de nuestros hombres notables, $\mathrm{y}$ preferiremos por ahora a los héroes de la Independencia. Cada retrato irá acompañado de un bosquejo biográfico, en el cual se condensarán los hechos más notables del personaje y los más importantes servicios prestados al país, a fin de que nuestro periódico sirva con el tiempo a manera de álbum nacional ("Historia". Papel Periódico Ilustrado 1/1, 6 Ag. 1881: 4)

El personaje histórico más representado en las portadas fue Simón Bolívar, quien era el referente fundamental del proyecto de la Regeneración por sus planteamientos centralistas, con los que se identificaba el Partido Conservador, y que además se contraponía a la imagen de Francisco de Paula Santander, el otro gran personaje histórico del proceso de Independencia con el que se identificaba el Radicalismo liberal y que por tanto era un símbolo antagónico para la Regeneración.

La imagen de Bolívar, además de ser parte de la primera página del número uno, fue incluida en otras siete ocasiones en la portada y repetidas veces en páginas interiores. Del primer volumen, la portada del número cuatro, del $1^{\circ}$ de noviembre de 1881, incluyó un grabado sobre la estatua elaborada por el escultor italiano Pietro Tenerani, que hoy se encuentra en el centro de la plaza principal de Bogotá, cuyo nombre precisamente es Simón Bolívar [Fig. 1]. De ese mismo volumen, la portada del número veintitrés, del 24 de julio de 1882 , presentó una reproducción del medallón de David D’Angers. En cuanto al volumen tres, la portada del número cincuenta y tres, del 28 de octubre de 1883, incluyó un grabado de la estatua ecuestre de la Plaza de

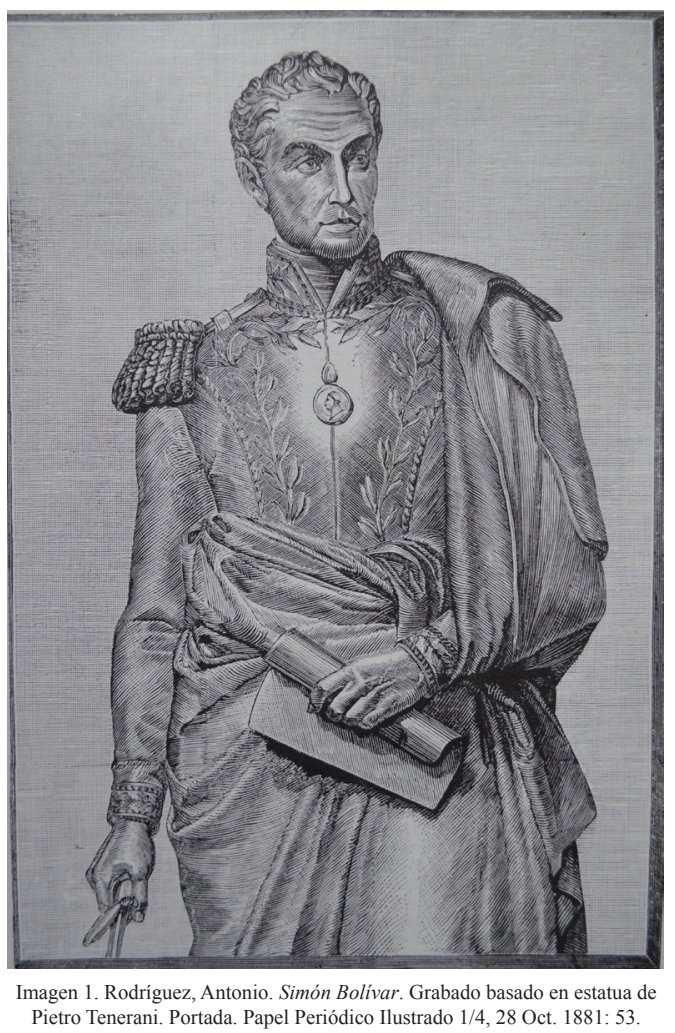

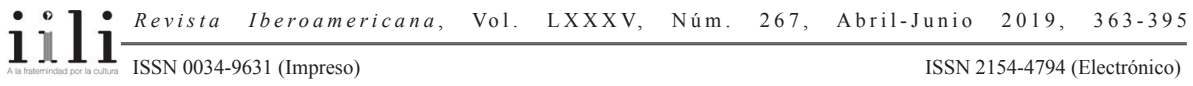


Bolívar en Caracas, y la del número setenta y dos, del 24 de julio de 1884 el de la estatua inaugurada en el Parque Centenario de Bogotá.

En el cuarto volumen, el suplemento del número setenta y siete, del 28 de octubre de 1884, fue un homenaje a Bolívar, que tuvo como portada una imagen alegórica a modo de ramo de guirnaldas con los nombres de las repúblicas de Bolivia, Perú, Ecuador, Venezuela y Colombia. De igual forma, el número noventa y cinco, del 24 de julio de 1885, publicó otra imagen alegórica con un busto de Bolívar rodeado de banderas y laureles, acompañado de un fragmento del himno a su nombre [Fig. 2]. Este grabado combinó distintos elementos alegóricos para la construcción de sentido en un marco

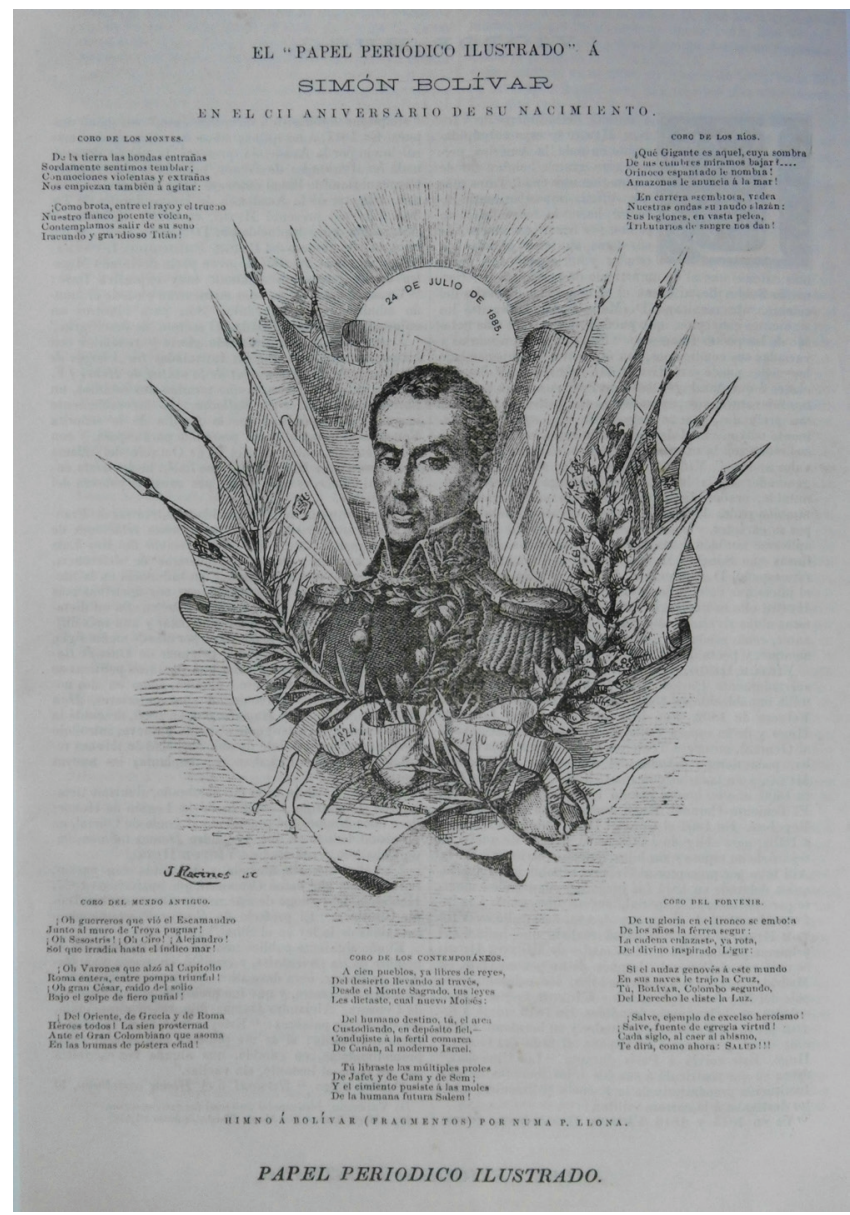

Imagen 2. Racínes, Julio. Simón Bolivar. Grabado basado en dibujo de De la Guardia. Papel Periódico Ilustrado 4/95, 24 Jul. 1885: 361.

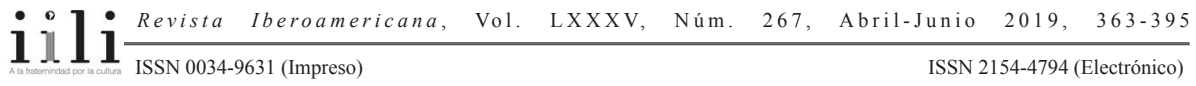


de condensación de imágenes referentes a un personaje histórico, banderas simbólicas y un sol resplandeciente, acompañadas de textos liricos como representación literaria y musical que destacaron al personaje y que posiblemente generaron una experiencia sonora al espectador en el proceso de observación y lectura de la imagen.

La última portada que incluyó una representación de Bolívar fue la del número ciento tres del quinto volumen, con fecha de 28 de octubre de 1886 [Fig. 3]. El grabado titulado Corona del genio, realizado por Antonio Rodríguez, sobre composición y dibujo de Urdaneta, representó los rostros de Alejandro Magno, Julio Cesar, Napoleón

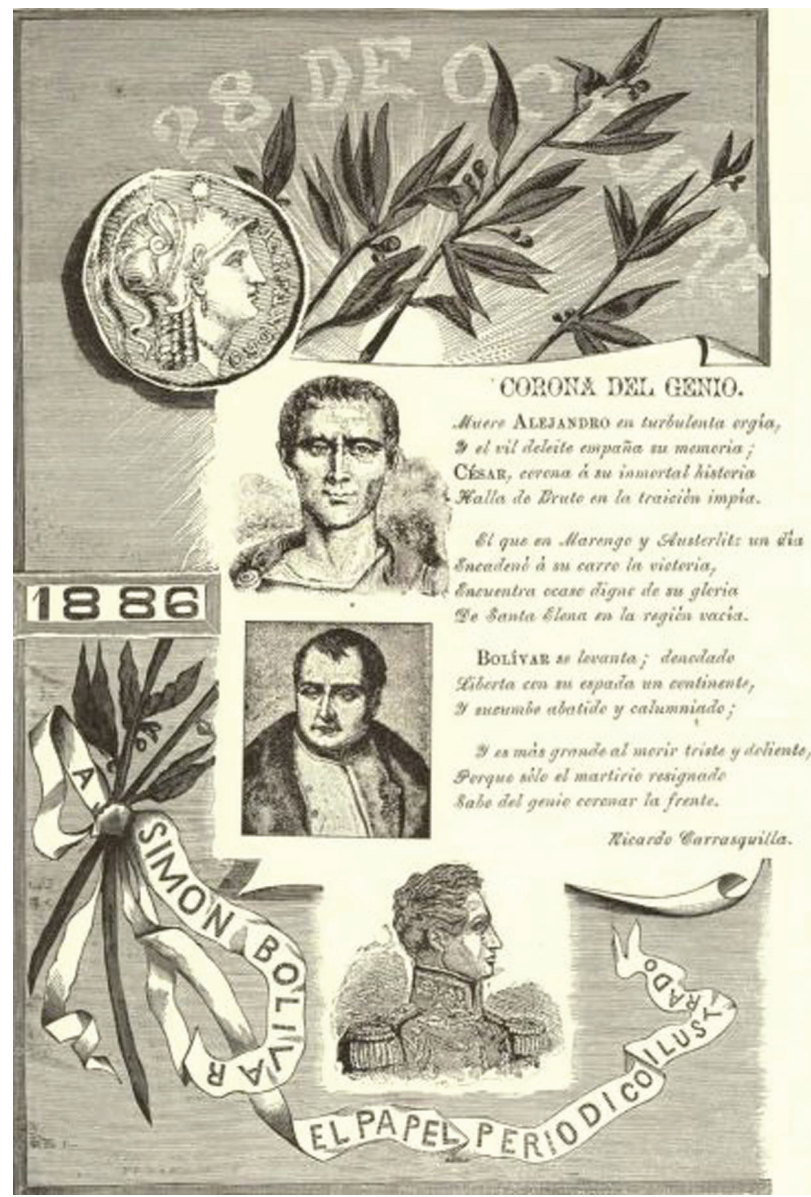

Imagen 3. Rodríguez, Antonio. Corona del Genio: Alejandro Magno, Julio Cesar, Napoleón y Bolivar. Grabado basado en dibujo de Alberto Urdaneta. Papel Periódico Ilustrado 5/103. 28 Oct. 1886: 97 .

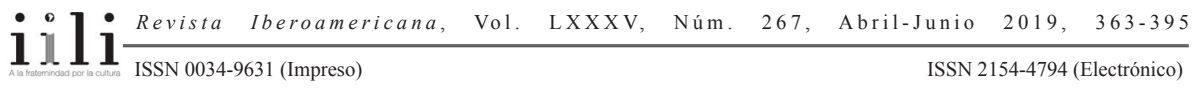


Bonaparte y Simón Bolívar, siendo la única imagen en que se vinculó a Bolívar con personajes de la historia del continente europeo. Si bien la imagen trata de destacar una importancia paralela entre los personajes y sus hazañas, el poema resalta la figura de Bolívar por encima de la de los otros personajes.

Ya con anterioridad, en el número cuatro del primer volumen, publicado el $1^{\circ}$ de noviembre de 1881, Manuel Briceño, en un texto elaborado en homenaje a Simón Bolívar, había hecho referencia a esta relación de personajes de la siguiente forma:

\begin{abstract}
Alejandro, César y Napoleón fueron guiados en sus empresas por la ambición personal, el mundo era estrecho a sus aspiraciones; a Aníbal lo dirigió el odio a los romanos; a Washington y a Bolívar los inspiraba el amor a la libertad.

[...] Alejandro aprendió el arte de la guerra al lado de su Padre Filipo, Aníbal en las guerras de España, César con las legiones romanas, Napoleón en las luchas gigantescas de la revolución, Washington con Braddock y Hove; Bolívar tuvo que adivinarlo todo, que inventarlo todo, y formó ejércitos y generales, estrategia y táctica.

[...] Alejandro no fue nunca vencido en los campos de batalla, pero le vencieron los vicios; César vio rara vez esquiva a la fortuna, y cedió a la ambición; Aníbal se dejó dominar de inmenso desaliento cuando los desastres continuos le anunciaron la ruina de la patria; Napoleón no supo sobreponerse a los favores de la fortuna, y mancho sus glorias con el manto de los Césares: no supo luchar contra la adversidad y sucumbió en Santa Elena; sólo Bolívar aparece fuerte en la adversidad, incorruptible en la fortuna, y si no tiene modelos en el pasado, probable es que no tenga tampoco imitadores en el porvenir. (“A Simón Bolívar Libertador”, 1 Nov. 1881, 54-56)
\end{abstract}

La exaltación e idealización de la figura de Bolívar lo transforma en un modelo a seguir, un modelo de héroe, objeto de culto, que "al idealizar valores y virtudes en un solo individuo excepcional, retoma una tradición clásica de hombres semidioses, con notables atributos físicos y morales que son predestinados a guiar a las masas y a cambiar al mundo" (Chicangana-Bayona 39). Cambio esencial en un momento de crisis de sentido y de reconfiguración del Estado-nación en el que el Papel Periódico Ilustrado, sin ser un periódico oficial o doctrinario, participó contribuyendo a afianzar las estrategias de legitimación del proyecto de la Regeneración.

\title{
VISUALIDAD MODERNA Y LA EXTENSIÓN-RESIGNIFICACIÓN DEL CAMPO DE LA ESTÉTICA
}

Durante la segunda mitad del siglo XIX, se desarrolló un proceso de transformación de la relación entre sujeto observador y los modos de representación que afianzó una visualidad moderna estrechamente relacionada con el funcionamiento del poder social y político y la reorganización del conocimiento y las instituciones, modificando las prácticas sociales y las experiencias cognitivas vinculadas a las imágenes. Esto fue posible porque, como afirma Jonathan Crary: "la visión y sus efectos son siempre

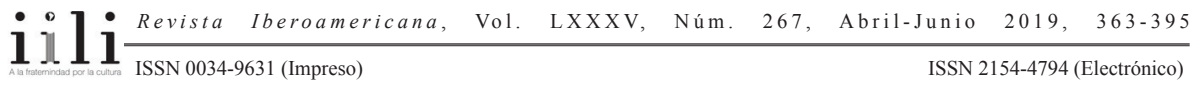


inseparables de las posibilidades de un sujeto observador que es a la vez el producto histórico y el lugar de ciertas prácticas, técnicas, instituciones y procedimientos de subjetivación" (21).

El afianzamiento de esa visualidad moderna se derivó del ensamblaje colectivo de varios elementos: la potencialización del mundo de los impresos; la proliferación de imágenes en diferentes formatos (pintura, grabados, estampillas, billetes, tarjetas de visita) a través de crecientes círculos de divulgación; el desarrollo y consolidación de códigos miméticos en los que la significación del mensaje estuvo determinado por el contexto de transición y la percepción de la imagen respondió a parámetros estratégicamente establecidos; la enunciación e imposición de un lenguaje político y cultural en los que se configuraron conceptos clave como los relacionados con el tiempo de la nación y la imposición de subjetividades; y por último la creación de instituciones relacionadas con la cultura y el mundo de la imagen.

Todos estos elementos definieron el contexto de un sistema de representación en el que la construcción de sentido del observador de la imagen estuvo atravesada por múltiples relaciones discursivas, sociales, políticas y culturales, tanto variables como continuas, que determinaron el ámbito en el que acontecía la percepción y que extendieron y resignificaron el campo de la estética y la distribución de lo visible y lo enunciable.

En este marco, la necesidad de ampliar las estrategias de divulgación de significados mediante el afianzamiento de una visualidad moderna y la ampliación de un lenguaje político y cultural, modificaron la relación del sujeto observador con el mundo perceptible y redefinieron su rol de ciudadano perteneciente a una nación y de sujeto histórico obligado a pensar nuevamente lo que entendía como historia.

Toda esta serie de modificaciones de las prácticas sociales y de las experiencias cognitivas vinculadas a las imágenes fue posible gracias a los adelantos tecnológicos experimentados desde mediados de siglo en el mundo de lo impreso, los cuales incrementaron ostensiblemente el volumen de documentos visuales en diferentes formatos y facilitaron la difusión en circuitos de divulgación de los que la imagen había estado relativamente ausente.

Si bien existieron importantes antecedentes de difusión de imágenes en impresos, la prensa ilustrada empezó su auge y divulgó ampliamente caricaturas y grabados desde mitad de siglo con periódicos como El Neogranadino, El Zipa y El Mosaico, ya referidos, Los Matachines Ilustrados. Periódico de los Muchachos i las Muchachas (1855), El Iris (1866), El Mochuelo (1877) y el Papel Periódico Ilustrado. La pintura, por su parte, más específicamente la de tipo histórico, caracterizada como representación realista o idealizada de personajes y sucesos relacionados con el tiempo de la nación, fue divulgada por medio de diferentes exposiciones, como las de 1871 y 1886 , así como también en libros, tarjetas de visita y publicaciones periódicas.

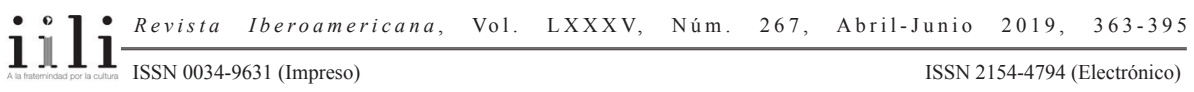


En cuanto a estampillas de correo, sistema que se estableció con la Ley Orgánica de Correos Nacionales del 27 de abril de 1859, su difusión se potencializó con el régimen federal al permitir que cada Estado soberano organizara su propio sistema de correos, con sus propios diseños y símbolos, pero conservando por lo general el escudo y el nombre. Situación similar experimentaron las imágenes en papel moneda cuando la Constitución Federal de 1863 organizó el sistema de Banca libre, el cual funcionó entre 1865 y 1886 y la ley 35 de 1865 autorizó la formación de instituciones bancarias con libertad de emisión de billetes en cada Estado.

De la mano de la amplia circulación de imágenes por múltiples circuitos de divulgación, el desarrollo y consolidación de códigos miméticos en la imagen, posibilitó configurar significados acordes al contex to de transición y a la enunciación e imposición de un lenguaje político y cultural como los relacionados con el tiempo de la nación y la imposición de subjetividades, puntos que abordaremos más adelante.

Con respecto a la creación de instituciones relacionadas con la cultura y el mundo de la imagen, después de algunos intentos infructuosos, ${ }^{3}$ la consolidación se logró con la Escuela de Grabado de Alberto Urdaneta y Antonio Rodríguez, institución que inició clases en abril de 1881 y de la cual surgieron importantes grabadores que colaboraron en el Papel Periódico Ilustrado y que contribuyeron a fortalecer el campo artístico colombiano.

Un año después, en 1882, la ley 67 (Diario Oficial 10.944) creó el Instituto de Bellas Artes conformado por cuatro escuelas: dibujo y grabado, arquitectura (Escuela Arrubla), pintura (Escuela Vásquez) y música (Escuela Guarín). La organización definitiva de esta institución se dio en 1886 con la creación de la Escuela Nacional de Bellas Artes, la cual cerró temporalmente en 1899 a raíz de la Guerra de los Mil Días (1899-1902), para posteriormente abrir y continuar definiendo el campo artístico colombiano de inicios del siglo XX.

Además del marco institucional, otro factor importante para la construcción de representaciones visuales a partir de imágenes impresas fue la existencia de personal capacitado relacionado con el área. Según el Almanaque y guía ilustrada de Bogotá para 1881, año en el que inicia actividades el Papel Periódico Ilustrado, la ciudad contaba con cuatro fotógrafos, dos litógrafos, siete grabadores, un grabador en madera,

Desde finales de la década de 1840 existieron academias privadas de corta duración en las que se formaron varios de los representantes de las artes de las décadas siguientes (Fajardo de Rueda 19-47). A nivel gubernamental se presentaron intentos como los de la Escuela de Artes y Oficios establecida por ley 22 de septiembre de 1867, la cual fue disuelta rápidamente y anexados sus estudiantes a la Escuela de Literatura y Filosofía de la Universidad Nacional, donde Alberto Urdaneta estaba encargado de las clases de dibujo, siendo reemplazado posteriormente por los pintores Ramón Torres Méndez y Pantaleón Mendoza (Córdoba 9-18). En 1873 el pintor mexicano Felipe Gutiérrez fundó la Escuela Gutiérrez, de carácter privado, y en ese mismo año, la ley 98 creó la Academia Vásquez. 
dos escultores, once pintores, cinco dibujantes, cinco agencias públicas y comerciales de libros y periódicos, once librerías, catorce imprentas y una biblioteca ambulante (Vergara y Velasco 144-63).

A la potencialidad de medio divulgativo, el desarrollo de la relación imagen conceptos, el marco institucional, y el personal capacitado se sumó que una preocupación importante del proyecto regenerador fue la relación de la moral católica con el plano de lo estético. "La idea básica era que el arte debía estar al servicio de la construcción del orden moral. Dos formas adquirió este modelo, por un lado un profundo hispanismo y, por otro lado, el moralismo temático" (Urrego 119). El Papel Periódico Ilustrado cumplió un importante papel en estos puntos en tanto que desde el ámbito iconográfico, las temáticas históricas y artículos relativos a costumbres religiosas, estableció parámetros que permitieron identificar una idea de continuidad histórica acorde a una herencia española, a la vez que propugnó un confesionalismo católico.

\section{UNA NUEVA LECTURA DEL TIEMPO DE LA NACIÓN}

Una de las estrategias más importantes para la reconfiguración del Estado-nación colombiano en la segunda mitad del siglo XIX y en el cual las imágenes jugaron un papel central fue la reformulación del equilibrio entre el pasado, el presente y el futuro de la nación. Para lograr este cambio conceptual, el proyecto político de la Regeneración planteó en una nueva lectura del relato de la nación que tuvo como objetivo legitimar el tiempo histórico propio a partir de una ruptura con el pasado cercano del Radicalismo, remitiéndose a una idea de continuidad con el espacio de experiencia que constituían la herencia española de la mano con el confesionalismo católico y el proceso de Independencia como momento fundacional de la nación, posibilitando, a su vez, un horizonte de expectativas fundamentado en la tradición.

Esta nueva lectura del tiempo de la nación constituyó la oficialización de un discurso visual e historiográfico que enlazó tres dimensiones temporales, de acuerdo con procesos históricos diferenciados por elementos de continuidad y discontinuidad. De esta forma, el relato histórico desde lo visual y lo escrito desplegó su utilidad político-pragmática para recurrir a "estratos de la experiencia y de lo que se puede experimentar, del recuerdo y de lo que se puede recordar y [...] lo olvidado o lo que nunca se ha transmitido" (Koselleck 286).

Este proceso de formación de una conciencia subjetiva de tiempo tuvo como objetivo construir un marco de legitimidad a partir de una ficción de homogeneidad cultural que resolviera la ausencia de una identidad nacional de carácter integrativo, producto de los constantes conflictos bélicos, las diferencias regionales y la concentración del poder político. Para lograr este propósito, las élites políticas y culturales procuraron, mediante imágenes y textos, reducir la nación a sus modos de representación, estableciendo una

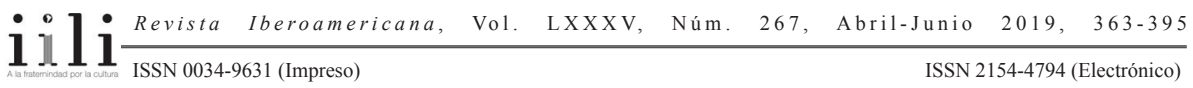


lectura organicista y genealógica con base en una condensación de temporalidades. ${ }^{4}$ Una síntesis de diferenciales de tiempo en los que imagen y texto configuraron la memoria y el olvido para imponer un mito de nación que constituyese una identidad colectiva.

La condensación de tres temporalidades desde el presente histórico como época de transición y aceleración histórica al espacio de experiencia de tiempo largo: herencia española y confesionalismo católico, el espacio de experiencia de tiempo corto: Independencia como momento fundacional, y el horizonte de expectativas fundamentado en la tradición, estableció una línea temporal con un elemento de discontinuidad que relegó voluntariamente al olvido todo el desarrollo histórico comprendido entre los años inmediatamente posteriores a la disolución de la Gran Colombia ${ }^{5}(1830)$ y el Radicalismo liberal ${ }^{6}$ (1863-1878). Interregno que se concibió como un fracaso en la construcción del Estado-nación y que por tanto no debía ser parte del relato sobre el tiempo de la nación. En el doble recurso temporal al pasado, la idea de continuidad histórica con Occidente empalmó el presente de transición con el pasado colonial como un regreso a los lazos con España, y el presente con el proceso de independencia, para establecer los fundamentos de lo que se debía entender por historia patria y así construir la conciencia del destino de la nación (Caro 76).

$\mathrm{Al}$ respecto, Miguel Antonio Caro, el intelectual conservador más importante de la segunda mitad del siglo XIX en Colombia, afirmaba que "la herencia cultural colombiana venía de España y a través de esta, de Roma" y que "las costumbres, la religión, la lengua y las tradiciones implantadas durante el período colonial habían cambiado muy poco al ser transmitidas de una generación a otra" (Zuleta 515-17).

En esta perspectiva, la idea de herencia española fue representada iconográficamente en tres repertorios: objetos, personajes y escudos, concentrando la mayor carga significativa en los grabados sobre personajes. De estos, el personaje central fue el conquistador español y fundador de la Capital, Gonzalo Jiménez de Quesada [Fig. 4]. Su imagen formó parte de la portada alegórica del primer número, y a partir de allí abrió, a modo de viñeta, el número inicial de cada volumen. Los otros dos personajes representados en línea de reivindicación de herencia española fueron Vasco Núñez de Balboa y Cristóbal Colón. Este repertorio buscó fortalecer elementos de identidad a partir de la labor realizada por los protagonistas de la conquista de América, enlazando el pasado del territorio americano a la historia de la cultura occidental. En cuanto a los

\footnotetext{
4 Ver: Palti, La nación como problema. Los historiadores y la "cuestión nacional".

5 La Gran Colombia fue el período comprendido entre 1819 y 1830 en el que los actuales territorios de Colombia, Venezuela, Panamá y Ecuador conformaron un solo país. Ver: Bushnell, El régimen de Santander en la Gran Colombia.

6 El Radicalismo liberal fue el período comprendido entre 1863 y 1878 , en el que los liberales radicales instauraron un modelo de organización política basado en el federalismo, procurando introducir reformas tendientes a la construcción de una nación secular, ilustrada y moderna. Ver: Sierra Mejía, El radicalismo colombiano del siglo XIX.
}

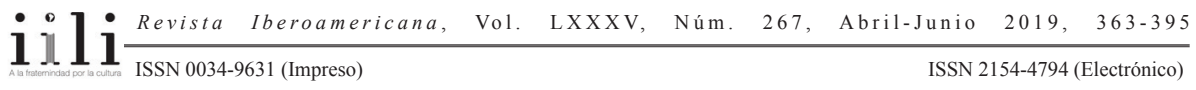




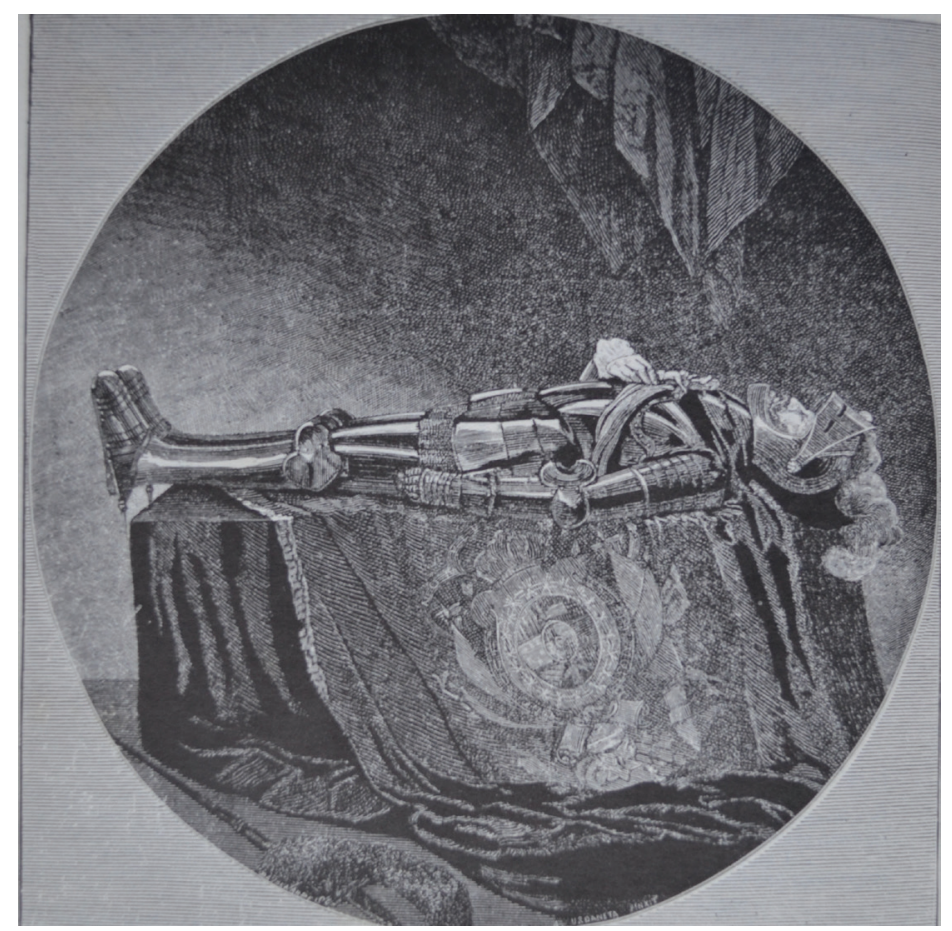

Imagen 4. Daudenarde. Gonzalo Jiménez de Quesada, muerto. Grabado basado en óleo de Alberto Urdaneta, 1878. Papel Periódico Ilustrado 1/7, 1 Ene. 1882: 116.

grabados sobre escudos, el objetivo fue rememorar el pasado colonial y sus costumbres, identificando en las ciudades y edificios la simbología heráldica española, generando una noción de territorio anexo a un pasado español. Esto se puede evidenciar en el grabado Escudos de Armas de algunas ciudades de Colombia, realizado por Julio Flórez a partir de dibujo y composición de Lázaro María Girón, quien elaboró el texto que acompaña al grabado, el cual lleva por título Apuntes de Heráldica [Fig. 5]. En esta imagen se representaron, alrededor del escudo de Cristóbal Colón, los escudos de ocho de las principales ciudades del Reino de Nueva Granada: Cartagena, Bogotá, Popayán, Panamá, Mariquita, Tunja, Cartago y Santa María la Antigua del Darién. El texto hizo énfasis en que las ciudades eran de origen español y se concentró en elementos referentes al siglo XVI.

Para la construcción del orden moral al que debía responder el nuevo proyecto de Estado-nación, las imágenes se enfocaron en propagar un confesionalismo católico, el cual fue representado a partir de seis repertorios iconográficos: Virgen María, Jesús, autoridades eclesiásticas, fachadas e interiores de iglesias, objetos y actos de

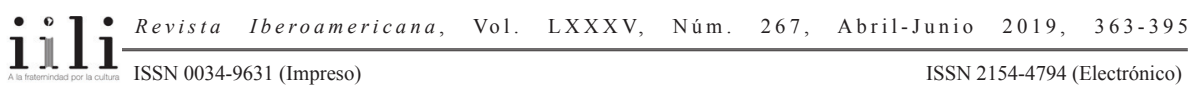




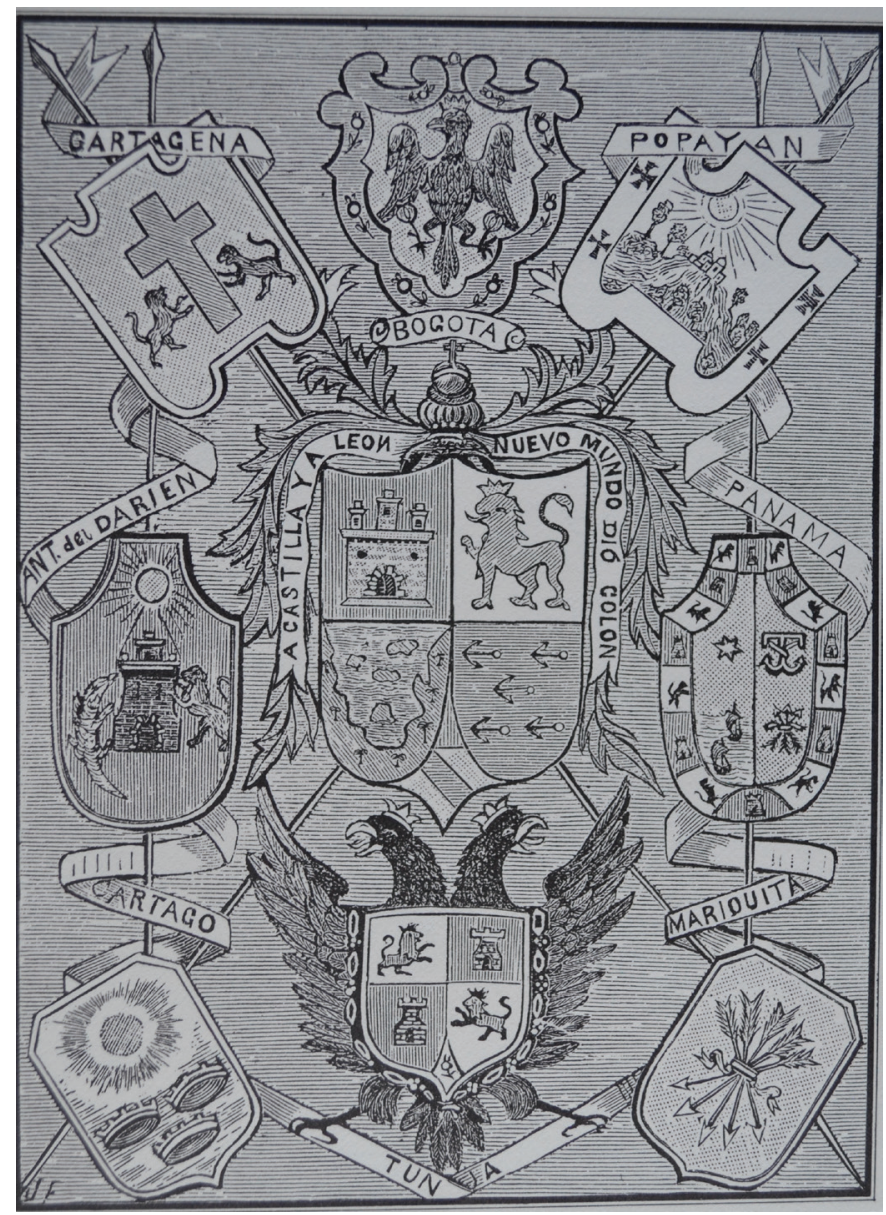

Imagen 5. Flórez, Julio. Escudos de Armas de algunas ciudades de Colombia. Grabado basado en dibujo de Lázaro María Girón. Papel Periódico Ilustrado 2/33, 31 Ene. 1883: 148.

culto. De estos repertorios la imagen más representada fue la de la Virgen María, pues posibilitaba fortalecer el culto mariano y promulgar al público femenino principios y valores relacionados con la prudencia, la discreción, la inocencia, la fidelidad, el cuidado del hogar y toda una serie de prácticas atribuidas a un ideal de mujer en la cultura decimonónica. En el número catorce del primer volumen, publicado el primero de mayo de 1882, se publicó el primer grabado a doble página dedicado a la Virgen. Se trató de un homenaje a la Virgen María con un grabado de A. Lefére de la escultura de Gustavo Doré [Fig. 6].

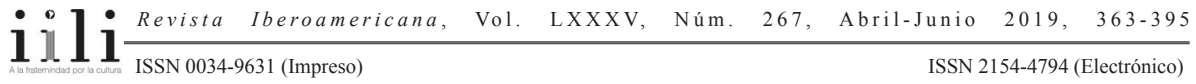




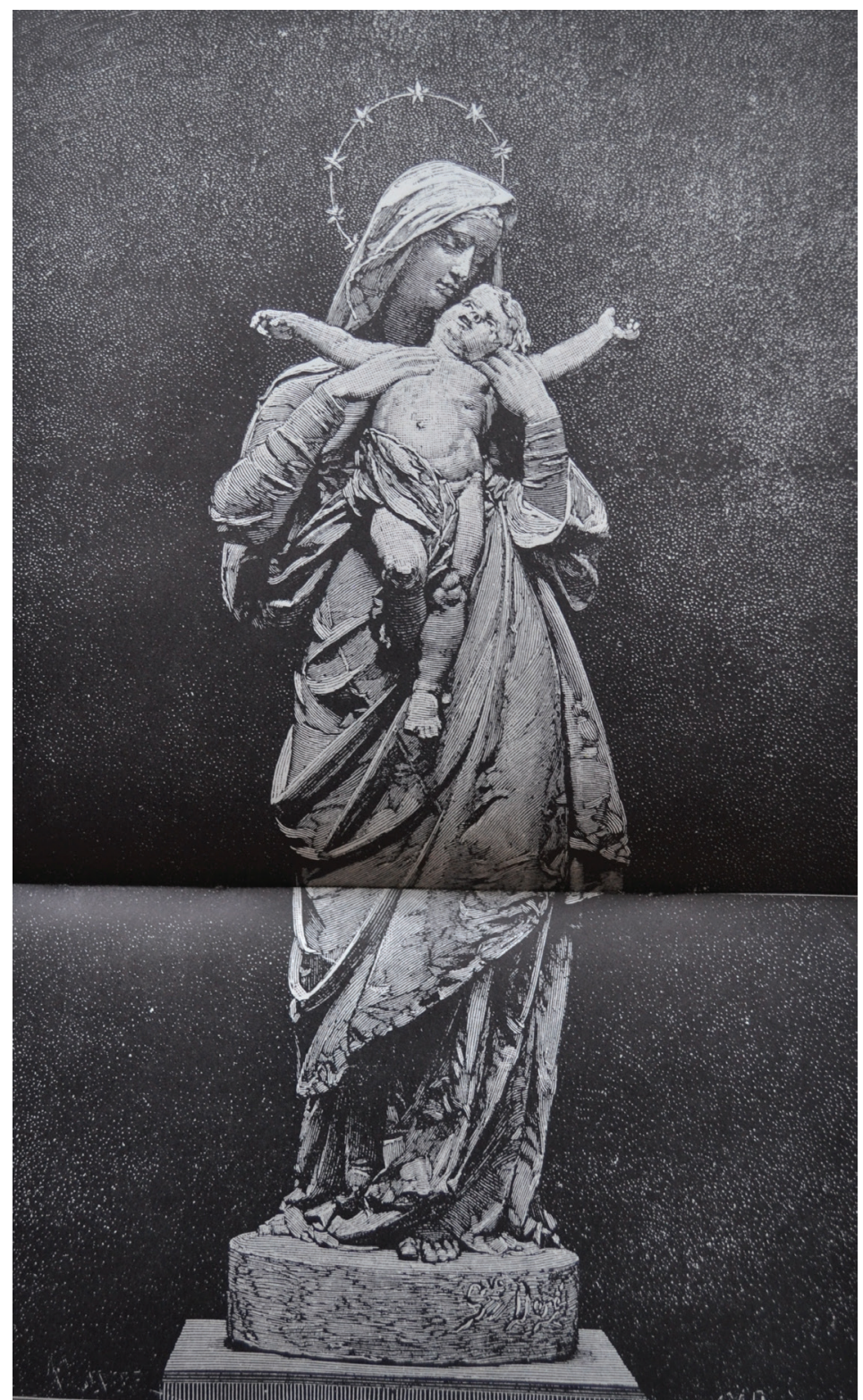

Imagen 6. Lefére, A. Virgen María. Grabado basado en escultura de Gustavo Doré. Papel Periódico Ilustrado 1/14, 1 May. 1882: 224-225.

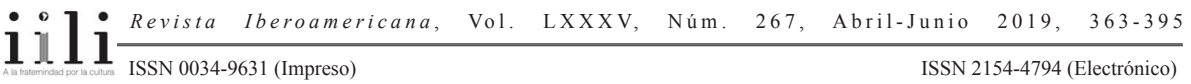


Además de fortalecer las creencias católicas con respecto a sus deidades con los grabados sobre episodios de la vida y muerte de Jesús, las numerosas representaciones de fachadas e interiores de iglesias buscaron relacionar las prácticas y creencias religiosas con lugares de culto, como se puede ver en la imagen del altar mayor de la Capilla del Sagrario [Fig. 7] y en la reproducción de la escultura de Paul Dubois titulada $\mathrm{La} \mathrm{Fe}$ [Fig. 8].

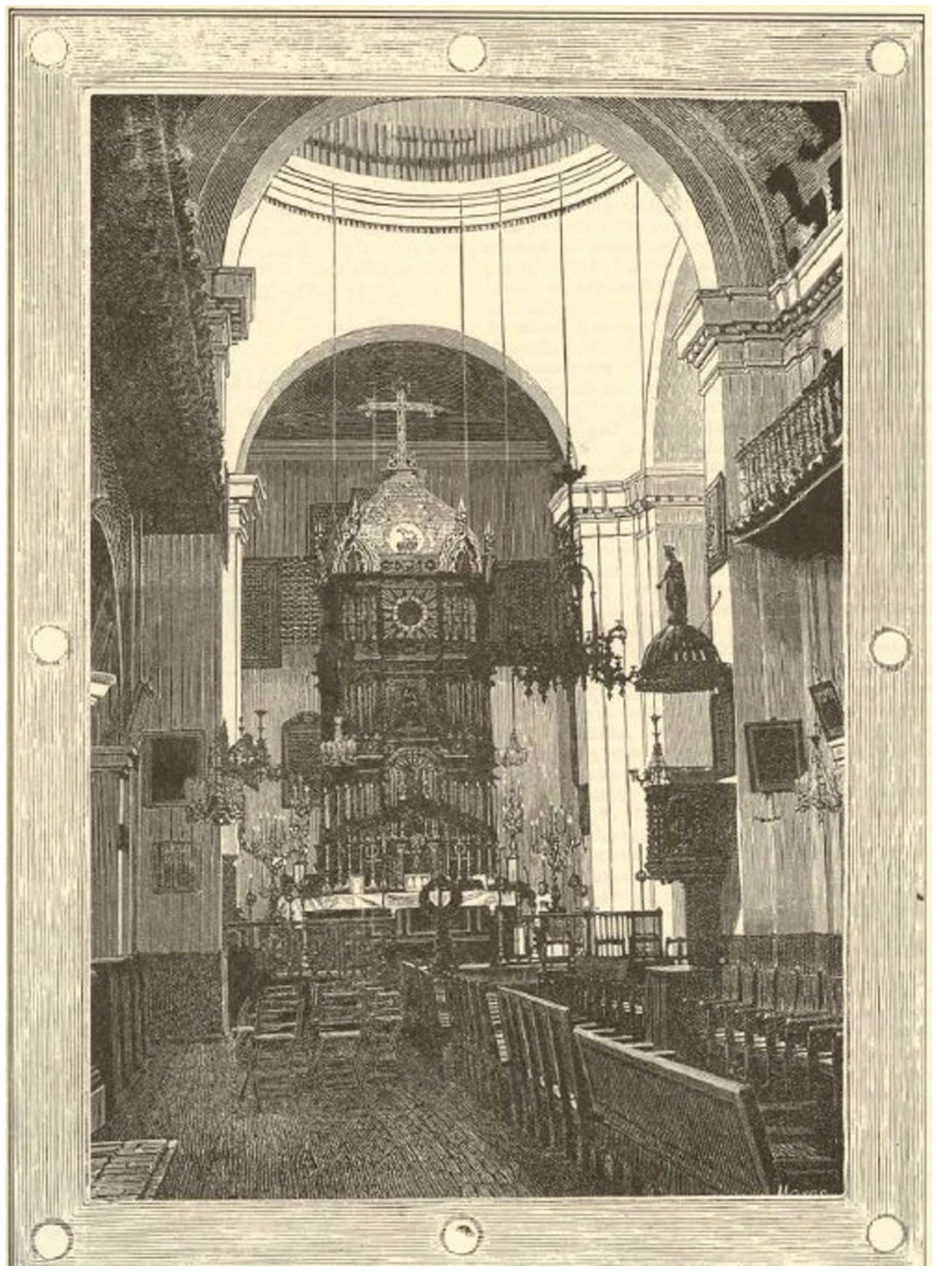

Imagen 7. Moros, Ricardo. Altar mayor de la Capilla del Sagrario. Grabado. Papel Periódico Ilustrado 5/105, 4 Dic. 1886: 137.

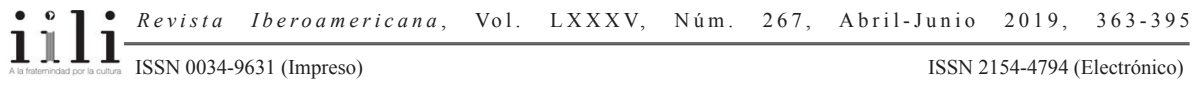




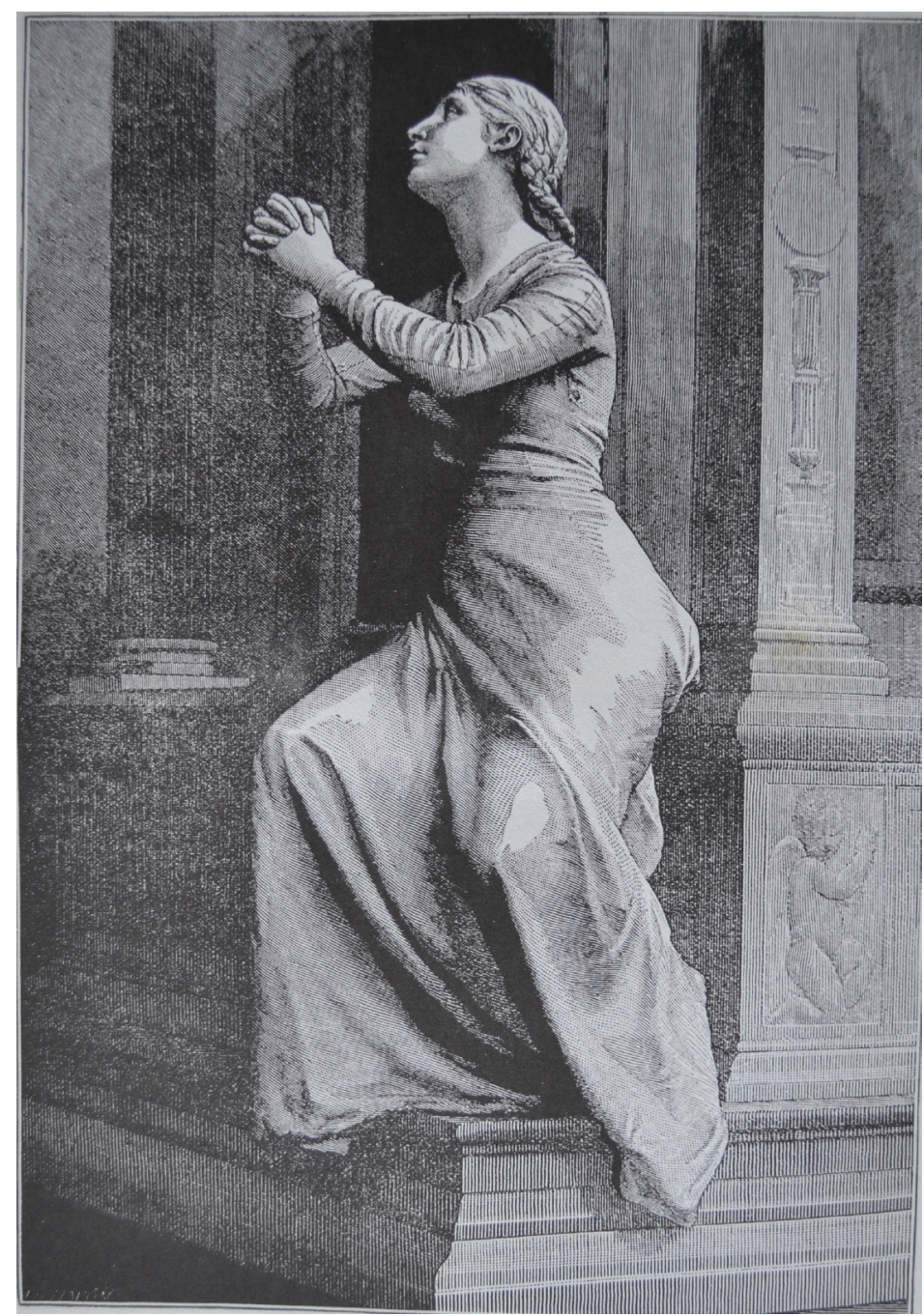

Imagen 8. $\mathrm{La} \mathrm{Fe}$. Grabado basado en escultura de Paul Dubois. Papel Periódico Ilustrado 1/19, 20 Jun. 1882: 304.

En cuanto a las imágenes sobre autoridades eclesiásticas, fundamentalmente arzobispos y algunos frailes, se correspondieron con el confesionalismo católico en tanto que estuvieron enfocados en defender la legitimidad de la jerarquía de la Iglesia, en alguna medida minimizada con las diferentes políticas establecidas por el Radicalismo liberal en las décadas anteriores.

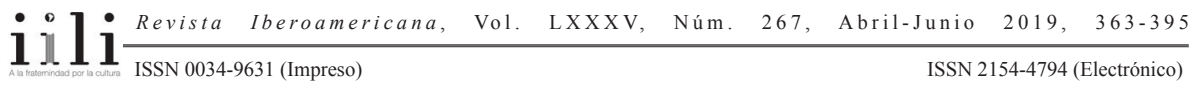


En este mismo marco de confesionalismo católico, la Constitución de 1886, redactada por Miguel Antonio Caro, declaró a la religión católica como la de la nación, a la vez que como elemento esencial del orden social. Un artículo determinante al respecto fue el número cuarenta y uno, el cual ordenó que la educación pública fuera organizada y dirigida en concordancia con la religión católica, rompiendo así con la principal bandera del Radicalismo liberal: el proyecto educativo y secular que posibilitara a la nación un mejor ingreso en la modernidad. ${ }^{7}$ El texto completo de la Constitución se publicó en el Papel Periódico Ilustrado el 22 de agosto de 1886.

Otro punto clave en los procesos de enunciación e imposición de conceptos mediante imágenes en el contexto de transición que implicó la reconfiguración del Estado-nación fue el relacionado con la construcción de una temporalidad vinculada con el proceso de Independencia como momento fundacional de la nación. Una idea que iconográficamente se había empezado a construir desde mediados de siglo con los aportes de pintores y litógrafos en libros, hojas sueltas y periódicos, pero cuya producción más extensa fue publicada en el Papel Periódico Ilustrado. Para ilustrar este marco temporal, el periódico estructuró los repertorios iconográficos a partir de cinco categorías: héroes o individuos, lugares o escenarios, objetos, medallas y monumentos.

Las imágenes de héroes e individuos buscaron crear lealtad e identidad con el proyecto de construcción de nación, constituyendo toda una imaginería cívica referente a un pasado legitimador estratégicamente construido. Estas imágenes en su gran mayoría, estuvieron enfocadas a fortalecer un relato historiográfico de historia patria, haciendo especial énfasis en la figura de Simón Bolívar, que como ya vimos, fue el referente fundamental del proyecto regenerador.

Además de las portadas comentadas, el Papel Periódico Ilustrado dedicó a la imagen de este personaje histórico tres números especiales en una sola entrega al final del volumen del segundo año. En este especial, Alberto Urdaneta reunió todos los grabados de portada publicados hasta el momento e incluyó su artículo titulado Esjematología del libertador. Un exhaustivo estudio iconográfico de la imagen de Bolívar, en el que compiló más de ciento ochenta imágenes en dibujo, pintura, escultura, grabado y efigies conmemorativas, organizándolas en cuatro agrupaciones: última fisonomía de Bolívar, perfiles, tenerani y fisonomías de la primera época.

Si bien el culto político a los héroes fue una práctica permanente durante el siglo XIX, los momentos más fuertes de promoción fueron aquellos relacionados con épocas de transición. El propósito del culto fue la divulgación e interiorización de un sentido político de identidad nacional, relacionando una narrativa imaginaria o construida del héroe, con su carácter de líder militar o de ciudadano. El carácter de imagen construida fue complementado con una retórica nacionalista dirigida a potencializar una ideología

Ver Rausch, La educación durante el federalismo.

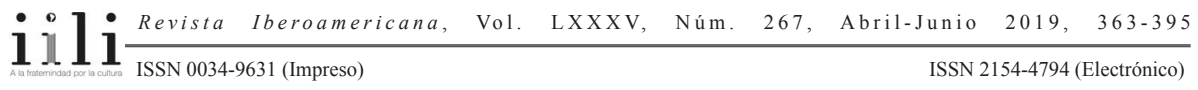


política persuasiva y popular apropiando y manipulando discursos y prácticas existentes. ${ }^{8}$

El culto a los héroes, y especialmente a Bolívar, ayudó a hacer visible y convincente un ideal de nación, el cual no solamente fue promulgado por medio de imágenes visuales, sino también con abundante producción de literatura, obras de teatro, ${ }^{9}$ música y múltiples rituales republicanos, especialmente conmemoraciones.

En cuanto a las representaciones de lugares, estas estuvieron enfocadas a evocar y construir imágenes mnémicas para la creación de una identidad nacional atravesada por una idea de tiempo histórico. Estas imágenes remitían a las tres dimensiones que Pierre Nora ha destacado como constitutivas de los lugares de memoria: una dimensión material, una dimensión funcional y una dimensión simbólica. ${ }^{10}$ Mediante la dimensión material las imágenes de lugares o escenarios eran objetivaciones culturales que remitían a un espacio colectivo, reconocido y cargado de presencia. Mediante la dimensión funcional cumplían la finalidad de remitir a un cuerpo de recuerdos específicos que implicaban un elemento temporal y mediante la dimensión simbólica conferían significado a las acciones vinculadas a ese espacio en un tiempo presente. Imágenes representativas de estas características fueron las relativas a conmemoraciones, como por ejemplo la publicada en agosto de 1883, a propósito de la inauguración del Parque del Centenario, el cual había sido construido en homenaje a los cien años del nacimiento de Bolívar [Fig. 9]. Esta imagen permitía vincular el lugar o escenario con la referencia al personaje histórico, la creación y difusión de recuerdos y memorias asociadas a su figura y la afirmación de significados políticos, sociales y culturales, acordes al proyecto de nación.

Los monumentos también cumplieron una función importante en la construcción de una temporalidad vinculada al proceso de Independencia como momento fundacional de la nación. Estos no solo se constituían en elementos poderosos y pedagógicos para inculcar el culto a los héroes y darle significado a una idea de historia patria, sino que además materializaban el recuerdo, hacían real el tiempo pasado y legitimaban la invención de la tradición. ${ }^{11}$ Fue de esta manera que la difusión de imágenes de la escultura conmemorativa le posibilitó, tanto al Radicalismo liberal, como al proyecto de la Regeneración, producir un discurso político que vinculó una idea de tiempo con la difusión de un sistema de valores, imágenes de dominio público, lugares permanentes

\footnotetext{
Sobre la creación del mito de héroe ver: Riall, Garibaldi: Invention of a Hero.

9 Un autor importante en este punto es Constancio Franco Vargas, dramaturgo, político y autor de textos escolares, quien además de dedicarse a estas actividades, coordinó la elaboración de una galería de retratos al óleo sobre personajes del proceso de Independencia. Sus obras de teatro tuvieron gran acogida y amplios comentarios en la prensa. De estas destacamos: Los próceres o el 20 de julio de 1810. Tragedia histórica en cuatro actos.

${ }^{10}$ Citado en Erll, Memoria colectiva y culturas del recuerdo.

${ }^{11}$ Ver Hobsbawm y Ranger, La invención de la tradición.
}

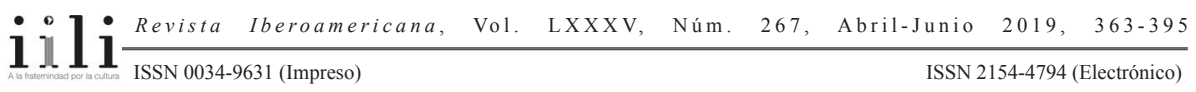




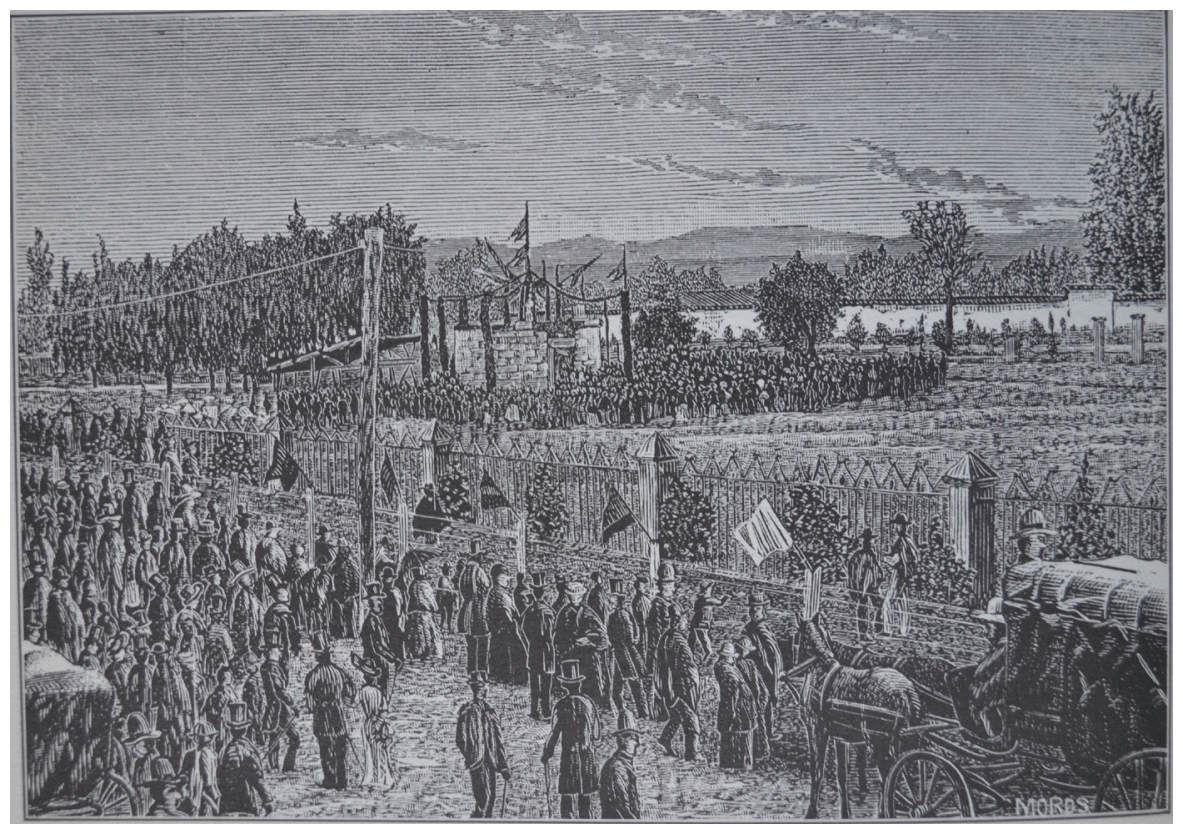

Imagen 9. Moros, Ricardo. Inauguración del Parque del Centenario, 1883. Grabado. Papel Periódico Ilustrado 3/50, 20 Ag. 1883: 24.

de memoria y una estética de lo urbano. ${ }^{12}$ Una imagen que permitió establecer estas relaciones, pero que además potencializó la idea de vínculo del proyecto de nación con la historia de occidente fue el proyecto de arco de triunfo que con motivo del centenario de Bolívar proyectó construir el Estado de Cundinamarca, obra que finalmente no fue realizada [Fig. 10].

Una imagen que condensó las tres temporalidades para el tiempo de la nación: desde el presente histórico como época de transición y aceleración histórica al espacio de experiencia de tiempo largo: herencia española y confesionalismo católico, el espacio de experiencia de tiempo corto: Independencia como momento fundacional, y el horizonte de expectativas fundamentado en la tradición, fue la de la primera portada del periódico [Fig. 11]. El complejo de representaciones incluyó un grabado sobre Bolívar realizado a partir del dibujo de François Désiré Roulin, que caracterizó a Bolívar como ciudadano y que buscó quitarle carga significativa a su imagen de militar: El texto de la sección Historia decía: "Ese que veis ahí, trazado con débiles líneas por la mano de la Amistad, es el retrato del grande hombre, del libertador de Sur-América: Bolívar. Lleva el común vestido de los ciudadanos, y ni en sus hombros

12 Ver Agulhon, Historia vagabunda. Etnología y política en la Francia contemporánea.

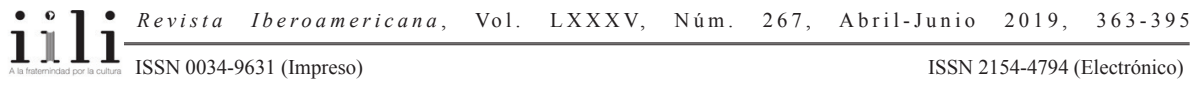




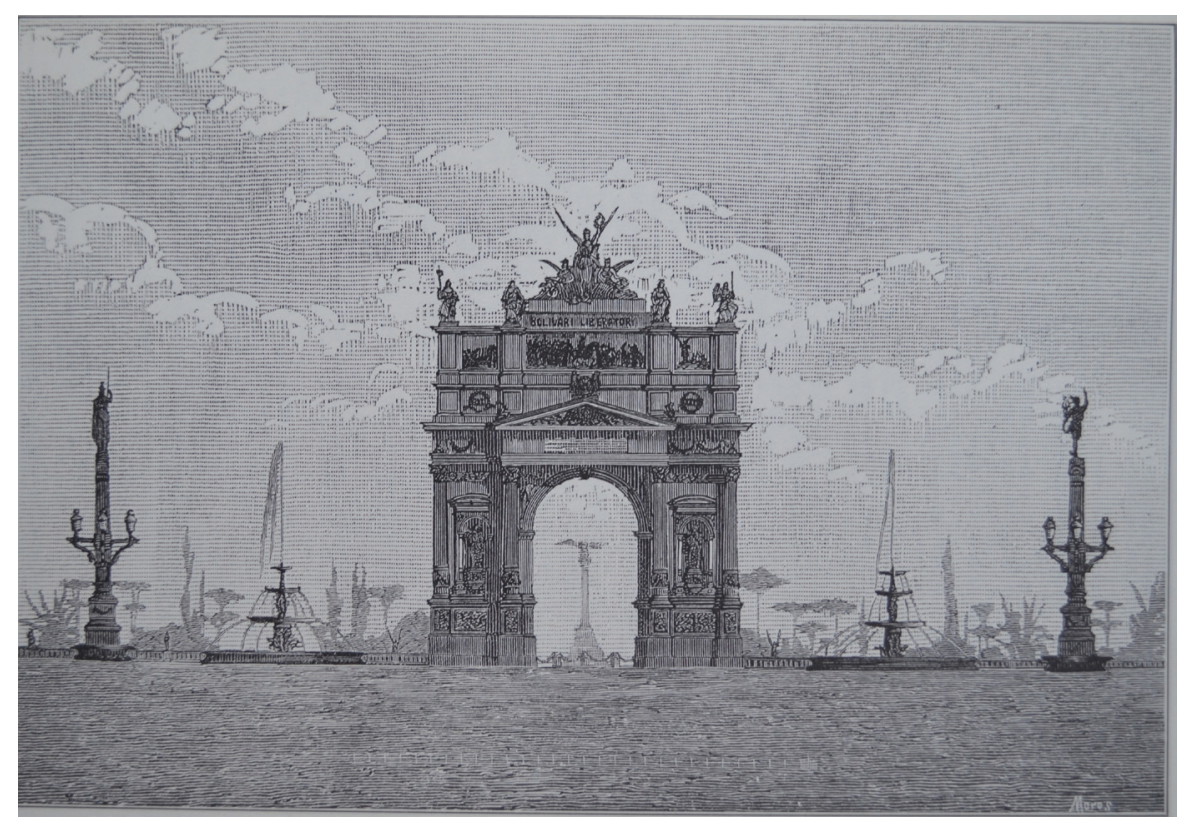

Imagen 10. Moros, Ricardo. Proyecto de Arco de Triunfo al Libertador. Grabado basado en Obra de Mariano Santamaría. Portada. Papel Periódico Ilustrado 3/72, 24 Jul. 1883: 392.

ni sobre su pecho resplandecen las insignias militares” (Ortiz, José Joaquín. “Historia”. Papel Periódico Ilustrado 1/1, 6 Ag. 1881: 5).

Es importante resaltar aquí que la producción de significados a partir de la imagen de Bolívar fue de la mano con las transformaciones conceptuales que requería el contexto político de transición en el que los espacios lingüísticos entraban en una crisis de sentido o respondían a intencionalidades directas para el establecimiento de un nuevo lenguaje político, y que uno de esos conceptos claves para la construcción del Estado-nación fue el de ciudadano, el cual durante el siglo XIX se debatió entre una perspectiva cívica y otra civil (si bien este es un debate heredado de la Antigüedad, como bien lo destacó John Pocock 31-41). La perspectiva cívica, enfocada en elementos comunitarios, con un lenguaje referenciado en la virtud, los deberes y la tradición, fue fundamental para el proyecto regenerador, en tanto que se diferenció de la perspectiva civil, la cual se concentró en elementos procedimentales y un ordenamiento normativo de corte liberal relacionado con los derechos. ${ }^{13}$ Fue en esta línea que la reivindicación de Bolívar vestido como ciudadano y no como militar buscó fundamentar la idea de nación como una comunidad de iguales, con una identidad soportada en la virtud cívica y el poder moral

\footnotetext{
13 Ver Irurozqui, La ciudadanía en debate en América Latina.
} 


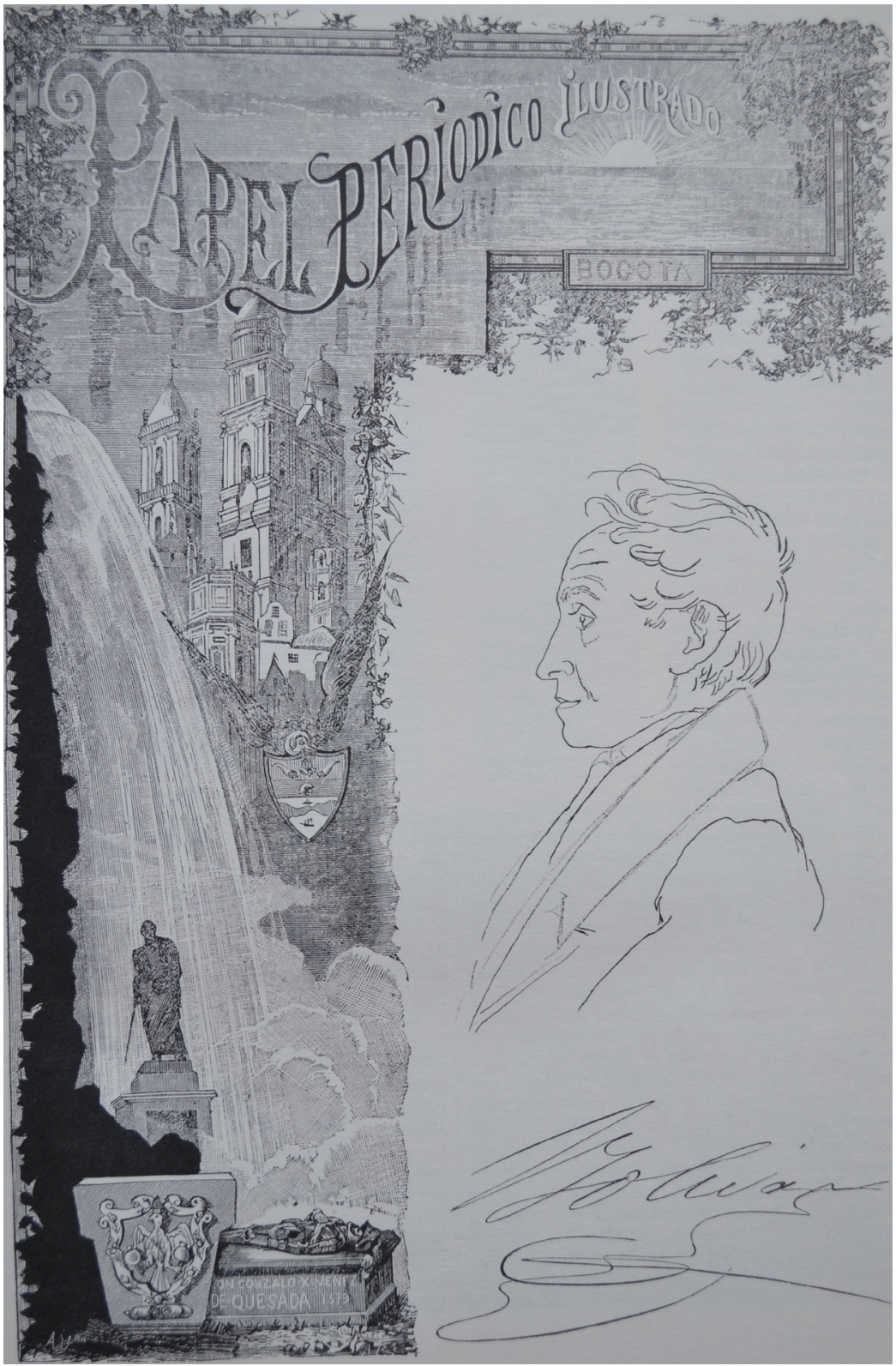

Imagen 11. Rodríguez, Antonio. Portada del Papel Periódico Ilustrado No.1. Grabado basado en dibujo de Alberto Urdaneta. Papel Periódico Ilustrado 1/1, 6 Ag. 1881: 1.

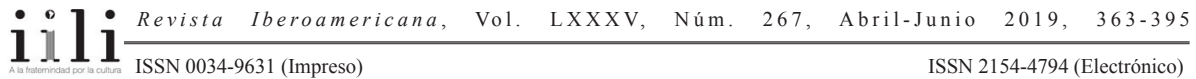


conservador, una idea de doble temporalidad, con alusión al espacio de experiencia de tiempo corto sustentado en el proceso de Independencia como momento fundacional de la nación y al futuro de los ciudadanos soportado en la tradición.

Entre las otras imágenes que componían el conjunto de la portada se encontraba la figura de Gonzalo Jiménez de Quesada muerto y el escudo de armas de la ciudad en primer plano, haciendo alusión al espacio de experiencia de tiempo largo con relación a una herencia española; la estatua de Bolívar elaborada por el escultor Italiano Pietro Tenerani, ubicada en la plaza principal de Bogotá desde 1846, como doble referencia al proceso de Independencia; la Cascada del Salto del Tequendama, y el Cóndor con el escudo de la nación, como presente histórico que deriva en el plano final en donde se encuentran la Catedral de Bogotá y la Iglesia de El Humilladero, que representa el nacimiento de la ciudad, ambas relacionadas con el confesionalismo católico como espacio de experiencia y la tradición como horizonte de expectativa y proyecto de nación católica, para terminar en el paisaje de la sabana que representa el futuro potencialmente realizable en esta línea de herencia española-confesionalismo católico -Independencia-presente histórico-futuro reivindicador de la tradición.

\section{AfIANZAMIENTO DE UN PRINCIPIO DE DISTINCIÓN}

El Papel Periódico Ilustrado hizo amplio uso de grabados y biografías con el propósito de crear modelos o prototipos de individuos que reunieran las cualidades políticas y morales acordes a la idea de ciudadano y el modelo de República. Mediante las biografías logró mitificar personas reales, caracterizando sus acciones a partir de valores y aspiraciones colectivas. Mediante los grabados, fundamentalmente retratos, logró hacer identificables los sujetos, creíbles sus acciones, presente el contexto histórico en que se desenvolvieron y urgente un horizonte de expectativas.

Los retratos, como destaca Acuña, funcionaron como modelo de distinción articulado a una visión conservadora del mundo, retomando "el canon neoclásico donde forma y contenido constituirán una unidad y por tanto los rasgos morales irán aparejados con una buena figura" (56-57). En este modelo, la construcción de la nación estuvo basada en la exclusión, en "el rechazo a las diferencias consideradas como signo de inferioridad" (64). Aun así, es importante destacar que el retrato no solamente cumplió su función principal de evocar la persona representada en su absoluta particularidad subrayando un valor jerárquico sino que además estaba dando forma a una expresión visual ligada a un acercamiento temporal, en el que las imágenes estaban condicionadas al tiempo en que se inscribían el retratado y el observador, atribuyendo por esto diferentes significados a la representación.

Con respecto a los personajes del presente, el retrato fue generador de notoriedad pública. En cuanto a personajes históricos de la colonia o el proceso de Independencia, el retrato, además de destacar un cuerpo de virtudes trasladadas a un concepto más

\begin{tabular}{l}
1110 Revista Iberoamericana, Vol. LXXXV, \\
\hline ISSN 0034-9631 (Impreso)
\end{tabular} 
reciente de ciudadano, hizo alusión a los hechos con que se vincularon los retratados e incluso cumplió funciones conmemorativas que marcaron una referencia temporal del espacio de experiencia al presente histórico.

Para reforzar el modelo de distinción jerárquica, más evidente en la referencia a personajes del presente, el periódico utilizó estrategias como el concurso que organizó para la designación de notabilidades colombianas, cumpliendo funciones de intermediación política que generaron efectos de posicionamiento político de personalidades civiles, en su mayoría identificadas con el Partido Conservador y algunas personalidades eclesiásticas. En el concurso convocado en el número 63 del 15 de abril de 1884, se estipuló que los votantes debían consignar en una papeleta los nombres de los personajes que consideraba los diez colombianos vivos más notables, destacando "obra u obras que cada cual haya producido, los servicios que haya prestado en bien de la patria, las cualidades que lo caractericen" y que posteriormente sus retratos serían publicados en alguno de los números. Los resultados de este posicionamiento político se publicaron en el número 71 del 20 de julio del mismo año, adjuntando las firmas de los diez personajes elegidos entre una muestra de ciento doce personas. Al momento del concurso, tres de los diez personajes finalmente seleccionados ya habían sido parte de la imagen de portada de alguno de los números anteriores. De estos, la figura más destacada fue la de Rafael Núñez, quien junto a Miguel Antonio Caro, fue el personaje más representativo de la Regeneración y que para ese año de 1884 era elegido por segunda vez presidente de la República [Fig. 12]. Ya en su primer período, entre 1880 y 1882, Núñez había sentado las bases de lo que posteriormente sería el nuevo proyecto de nación, decretando la devolución de los bienes confiscados a la iglesia durante el Radicalismo liberal, el regreso de los obispos desterrados y el cambio de la ley de orden público.

El LADO OSCURO DE LA MODERNIDAD. IMPOSICIÓN DE SUBJETIVIDADES Y NEGACIÓN DEL OTRO

Todas estas prácticas de jerarquización y distinción desde la imagen, inscritas en una nueva lectura del tiempo de la nación, no solamente relegaron al olvido algunos pasajes históricos de la historia republicana, sino que también negaron experiencias étnicas reinterpretando el pasado de comunidades indígenas y negras y condicionando su presente y su futuro; proceso que también se realizó mediante el uso de diversos marcos institucionales y múltiples dispositivos de control.

Como bien ha resaltado el historiador Mauro Vega, el uso del término "salvaje" en la legislación (Ley 89 de 1890) para referirse a las comunidades indígenas y su exclusión del marco jurídico general, es un ejemplo claro de negación del otro desde la dicotomía civilización-barbarie, una negación del otro incompatible con la nación, una dicotomía que "forjó una cierta imagen institucionalizada del país, proporcionando los recursos semánticos y simbólicos con los que se forjaron los discursos nacionalistas" (61).

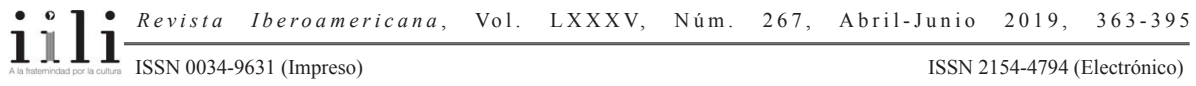




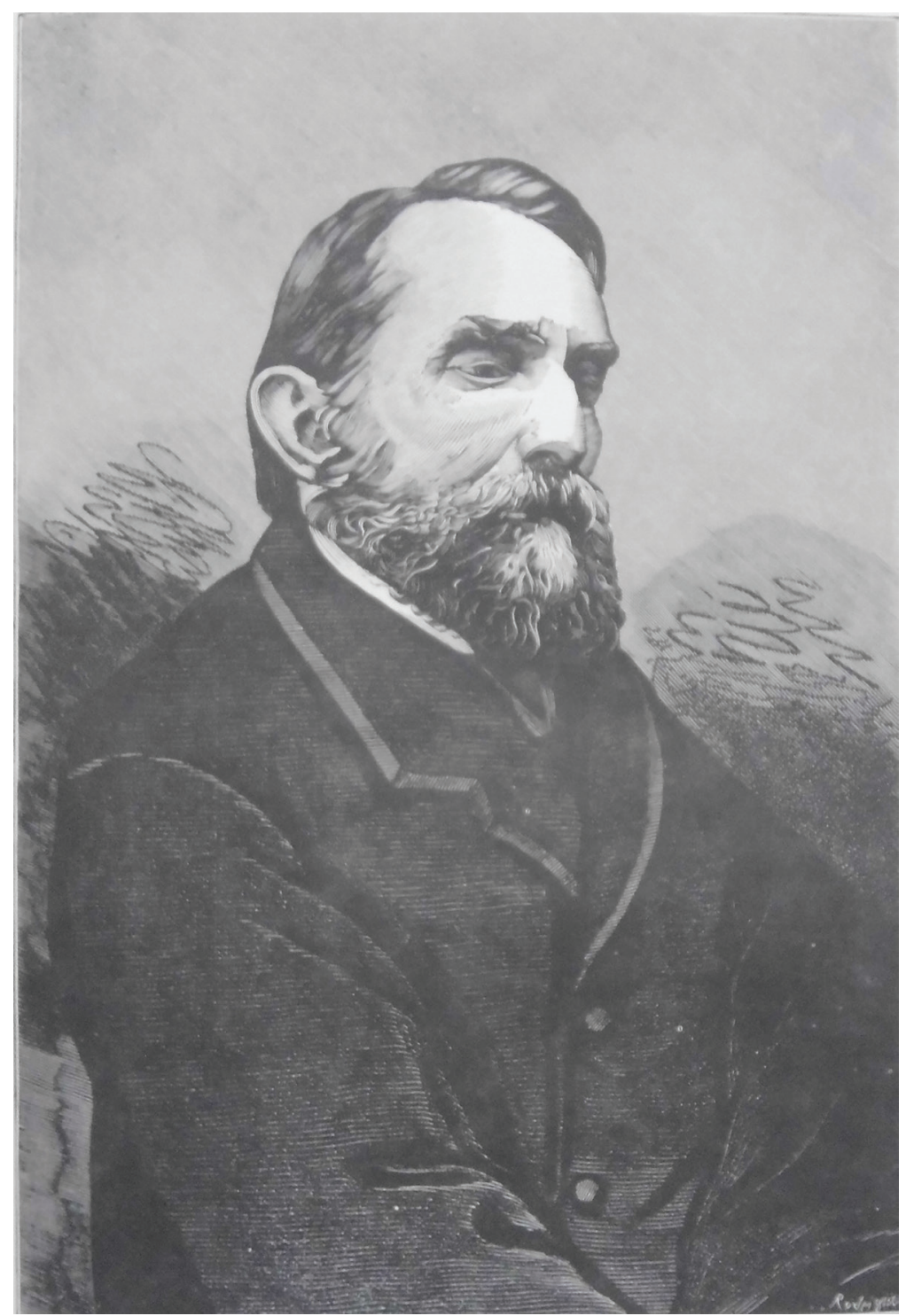

Imagen 12. Rodríguez, Antonio. Rafael Núñez. Grabado basado en fotografía de Racínes y Villaveces. Portada. Papel Periódico Ilustrado 1/12, 1 Abr. 1882: 12.

El uso de este criterio epistemológico de negación con el que las élites impusieron su visión del mundo se puede identificar en el texto que acompañó la imagen del recluta,

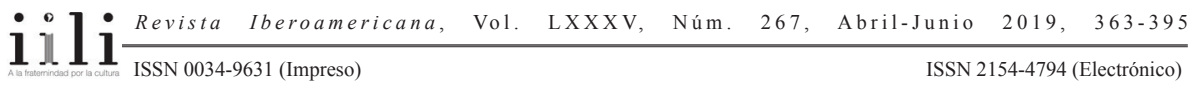


incluida en el primer número del periódico [Fig. 13]. El texto caracterizó al soldado indio como un salvaje, un abnegado que renunciaba a sus propios intereses, dispuesto a la muerte y que solo era humanizado al demostrar adhesión por la república (Pérez 74). El texto decía:

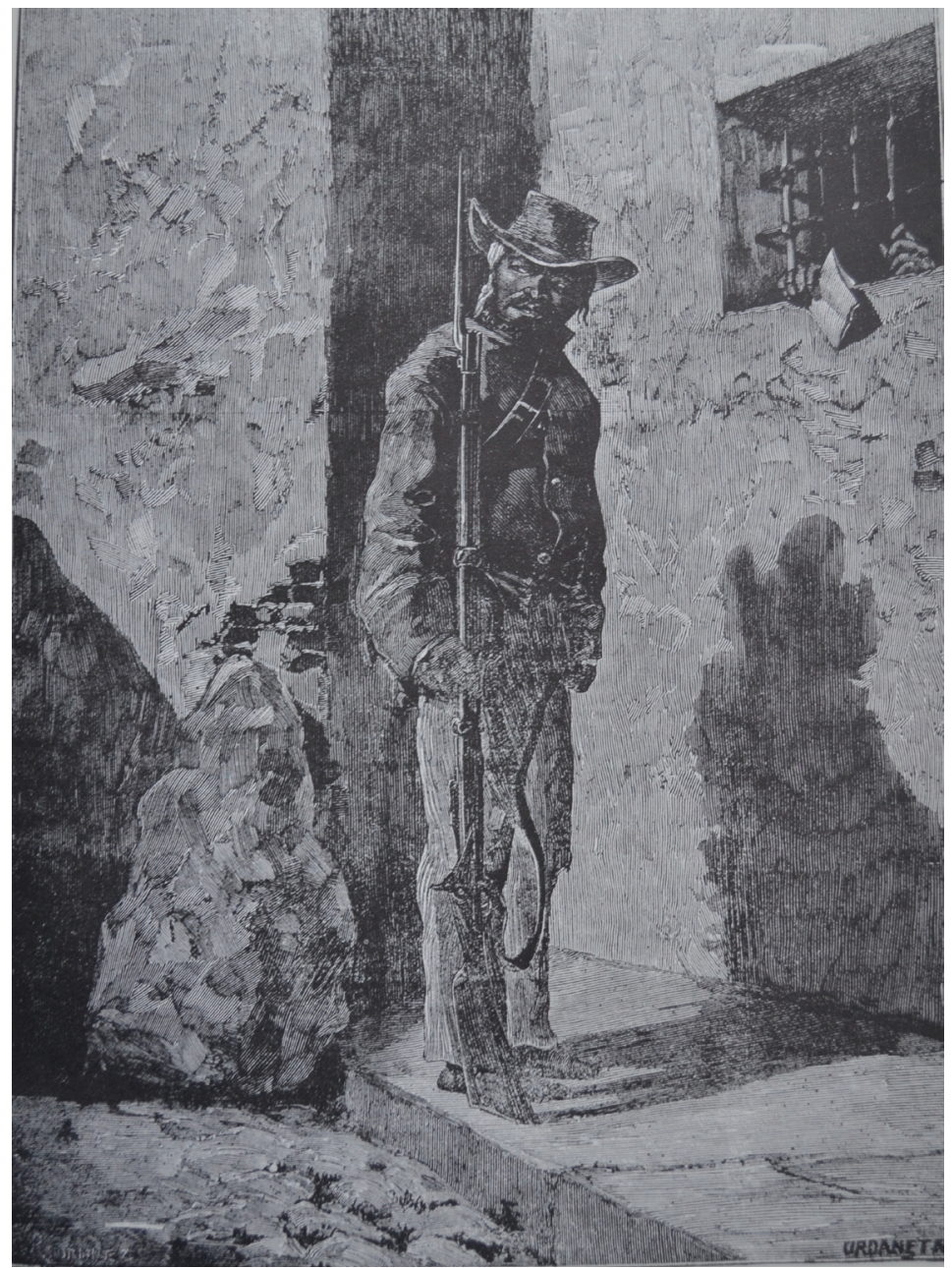

Imagen 13. Rodríguez, Antonio. El Recluta. Grabado basado en dibujo de Alberto Urdaneta. Papel Periódico Ilustrado 1/1, 6 Ag. 1881: 11.

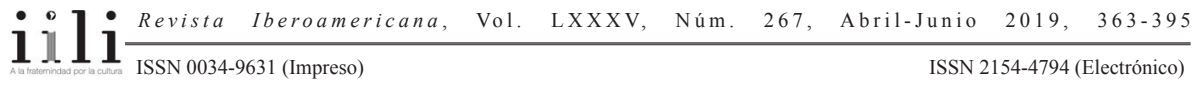


El recluta estaría indudablemente incluido en el Reino animal, si más de una vez no hubiese manifestado su adhesión a la República. Lo único que le es esencialmente necesario saber es ignorarlo todo; no debe ni pensar, pues no sirviera entonces para el objeto a que se lo destina: él está condenado a pensar por cabeza ajena y a hablar por la boca de un fusil, que es indudablemente el medio más adecuado para convencer a los demás. (Carrasquilla, Francisco de Paula. "El recluta". Papel Periódico Ilustrado 1/1, 6 Ag. 1881: 12)

Entre las otras representaciones visuales de los indígenas que incluyó el periódico destacan los grabados de la serie de artículos que se publicó bajo el nombre de "El Dorado", en la que se enfatizó en las costumbres domésticas, prácticas sociales, objetos [Fig. 14], sepulcros [Fig. 15], y lugares de culto de las poblaciones indígenas al momento de la conquista, aludiendo a grados de civilización y a la utilidad de estas imágenes y textos para futuros estudios etnológicos. Esta serie evidenció un trabajo de construcción

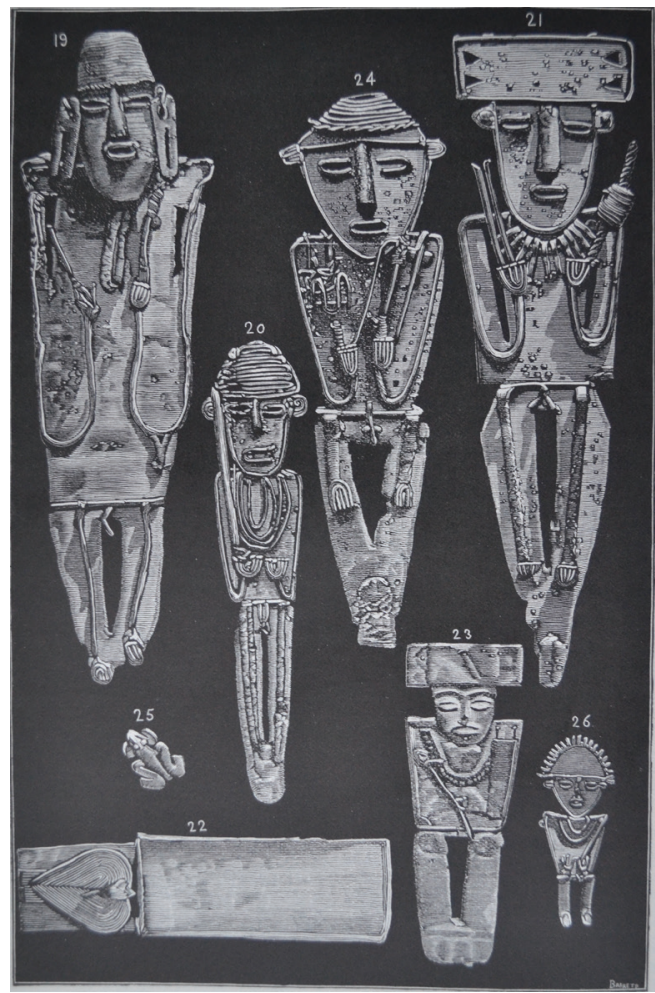

Imagen 14. Barreto. Figuras halladas recientemente en una huaca cerca de Quetame. Grabado basado en fotografía de Racínes. Papel Periódico Ilustrado 1/21, 10 Jul. 1882: 336. 


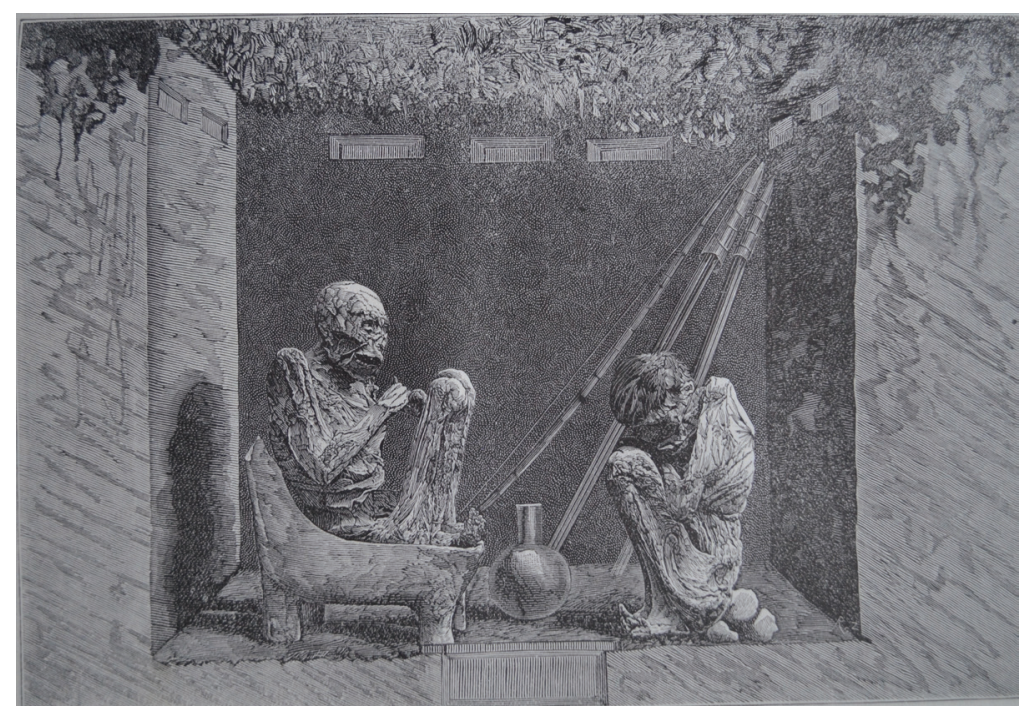

Imagen 15. Rodríguez, Antonio. Sepulcro de los aborigenes de Antioquia. Grabado basado en dibujo de Urdaneta. Papel Periódico Ilustrado 1/16, 20 May. 1882: 257.

del pasado de las comunidades indígenas, un pasado diferente al del ciudadano de la nación, que permitía identificar diferencias en sus grados de civilización, entre los aparentes avances de una y el estancamiento de la otra con respecto al presente y que a su vez adjudicaba un futuro basado en un concepto de tradición en dos perspectivas: tradición católica como proyecto y tradición indígena como inmovilización, retraso y obstrucción a un proyecto moderno de nación, razón por la cual se justificaba el establecimiento de prácticas civilizatorias por medio de misiones.

Es claro, como afirma Amada Carolina Pérez, que en el contexto histórico decimonónico al que perteneció el Papel Periódico Ilustrado, "la raza asociada a la fisonomía y al carácter no es sino uno de los elementos que se pone en juego a la hora de establecer las clasificaciones entre tipos, y de separar a los notables de las colectividades" (89). Pero este elemento de clasificación a partir de la raza fue aún más fuerte en la negación y casi invisibilización de las comunidades negras. Ya en la estructura de dominación de identidades desde la colonia, el negro había estado siempre más abajo del indio. Incluso su pasado reciente los vinculaba con la esclavitud. Mientras que la esclavitud indígena fue abolida en 1542, la esclavitud del negro se prolongó tres siglos más, hasta el 21 de mayo 1851, cuando el presidente José Hilario López estableció la abolición legal de este sistema. Esto quiere decir que entre perder la condición legal de esclavo y la representación que otros hicieron en imágenes y textos en el periódico que comentamos habían pasado tan solo tres décadas.

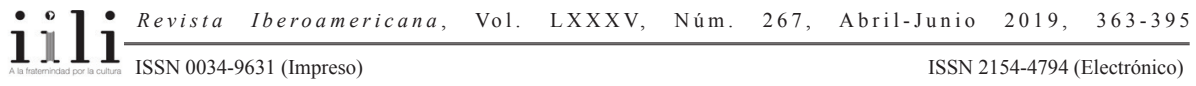


Los distintos grados de negación que el periódico hizo entre indígenas y negros se evidenciaron en sus caracterizaciones. Mientras que los indígenas fueron representados a partir de elementos como costumbres, vestido y lenguaje para definir grados de civilización, además de la posibilidad de desarrollar estudios etnológicos, los negros fueron mencionados a partir de rasgos fenotípicos y su posible inclusión como sujetos se dio en la medida en que fueron mediadores históricos, culturales o militares con el proyecto de nación. Esto se evidencia en los tres únicos grabados que sobre personas de raza negra se incluyeron en el periódico. El primero sobre Matea Bolívar [Fig. 16], la nana del libertador, en cuyo texto de acompañamiento la alusión se enfoca principalmente hacia la vida de Bolívar. El segundo sobre Leonardo Infante, el héroe y mártir de la Independencia con una valoración un poco ambigua por su acción militar, y el tercero, el homenaje a Candelario Obeso, el poeta fallecido que detentaba un papel intermedio entre los personajes notables y los tipos sociales.

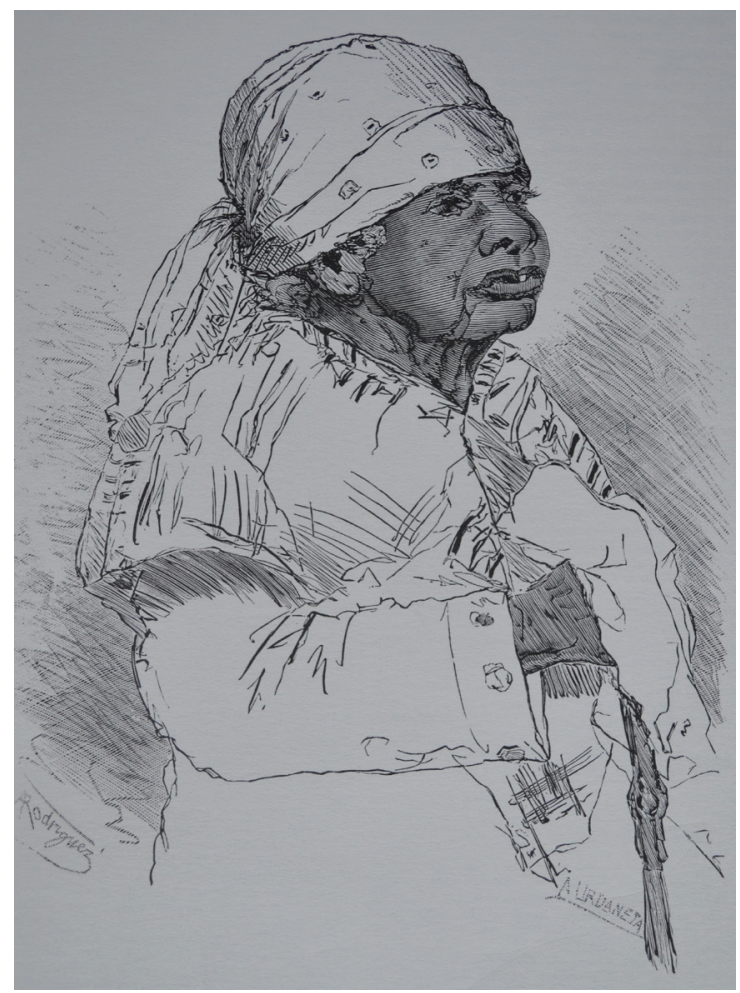

Imagen 16. Rodríguez, Antonio. Matea Bolívar: Ama de brazos del libertador. Grabado basado en dibujo de Alberto Urdaneta. Papel Periódico Ilustrado 3/53, 28 Oct. 1883: 80 . 
CONSIDERACIONES FINALES

Las grandes transformaciones históricas, sociales y culturales experimentadas durante la segunda mitad del siglo XIX en Colombia, configuraron una modernidad compleja que continuó desarrollando sus características hasta bien entrado el siglo XX. En el proceso de construcción del Estado-nación que caracterizó este período, la transformación de la opinión pública fue de la mano con una cada vez más extensa cultura visual, lo cual generó todo un abanico de experiencias estéticas potencializadas por el poder epistemológico de la imagen. Aun así, la cultura visual no dependió estrictamente del campo de lo político.

La transformación de la cultura visual y la ampliación del público receptor fueron posibles a partir de diferentes, y no siempre estables, medios de divulgación de imágenes como prensa, pintura, estampillas, billetes de banco o tarjetas de visita, los cuales incrementaron el potencial de las prácticas representacionales, sus significados y sus efectos, derivando en una expansión del ámbito de observación y percepción y por tanto en una extensión del campo de la estética.

La doble transformación de difusión y recepción de significados y conceptos a partir de imágenes, generó una reformulación del sujeto observador y del otro observado, como productos históricos y objetos de prácticas, técnicas, instituciones y procedimientos de subjetivación. Como parte de este proceso se estableció una lectura del tiempo de la nación que hizo referencia a varias temporalidades, determinando la experiencia, identidad, negación y futuro de los ciudadanos que hicieron parte del proyecto de nación, así como también de los sujetos políticos que fueron considerados marginales a este.

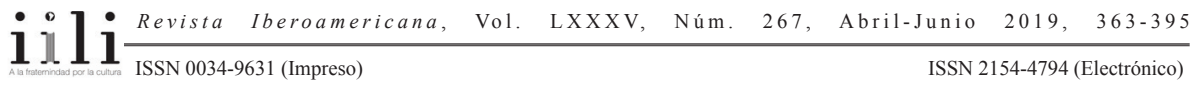




\section{BiBLIOGRAFÍA}

Acuña Pietro, Ruth. El Papel Periódico Ilustrado y la génesis de la configuración del campo artístico en Colombia. Tesis de Maestría en Sociología de la Cultura. Bogotá: Universidad Nacional de Colombia, 2002.

Agulhon, Maurice. Historia vagabunda. Etnología y política en la Francia contemporánea. México: Instituto de Investigaciones Dr. José María Luis Mora, 1994.

Anderson, Benedict. Comunidades imaginadas. Reflexiones sobre el origen y la difusión del nacionalismo. México: Fondo de Cultura Económica, 1997.

Briceño, Manuel. “A Simón Bolívar Libertador”. Papel Periodico Ilustrado 1/4, 1 nov. 1881: 54-56.

Bushnell, David. El régimen de Santander en la Gran Colombia. Bogotá: El Ancora Editores, 1985.

Cardona Zuluaga, Patricia. "Del héroe mítico, al mediático. Las categorías heroicas: héroe, tiempo y acción”. Revista Universidad EAFIT 42/ 144 (2006): 51-68.

Caro, Miguel Antonio. Ideario hispánico. Bogotá: Editorial Cosmos, 1952.

Castaño Zuluaga, Luis Ociel. La prensa y el periodismo en Colombia hasta 1888. Una visión liberal y romántica de la comunicación. Medellín: Academia Antioqueña de Historia, 2002.

Córdoba, Estella María. "La Escuela de Artes y Oficios de la Universidad Nacional de Bogotá y su organización entre 1867 y 1874”. La Universidad Nacional en el siglo XIX. Documentos para su historia: Escuela de Artes y Oficios, Escuela Nacional de Bellas Artes. Estela Restrepo Zea, comp. Bogotá: Universidad Nacional de Colombia, 2004.

Crary, Jonathan. Las técnicas del observador. Visión y modernidad en el siglo XIX. Murcia: Centro de Documentación y Estudios avanzados de Arte Contemporáneo -Cendeac, 2008.

Chicangana-Bayona, Yobenj. "Contando una historia nacional: la configuración de la iconografía sobre la Independencia”. Las historias de un grito. Doscientos años de ser colombianos. Exposición conmemorativa del Bicentenario. Bogotá: Museo Nacional de Colombia, 2010. 37-74.

Diario Oficial, 1882. Codificación Nacional de Leyes de Colombia desde 1821, hecha bajo la dirección del Consejo de Estado. Tomo XXXII, 1882. Bogotá: Imprenta Nacional, 1951.

Erll, Astrid, Memoria colectiva y culturas del recuerdo. Bogotá: Universidad de Los Andes, 2012.

Fajardo de Rueda, Marta. "Documentos para la historia de la Escuela Nacional de Bellas Artes, 1870-1886". La Universidad Nacional en el siglo XIX. Documentos para

\begin{tabular}{l}
1110 \\
\hline ISSN 0034-9631 (Impreso)
\end{tabular} 
su historia: Escuela de Artes y Oficios, Escuela Nacional de Bellas Artes. Estela Restrepo Zea, Compiladora. Bogotá: Universidad Nacional de Colombia, 2004. González, Beatriz. La caricatura en Colombia a partir de la Independencia. Bogotá: Banco de la República, Biblioteca Luis Ángel Arango, 2009.

Hobsbawm, Eric y Terence Ranger, eds. La invención de la tradición. Barcelona: Editorial Crítica, 2002.

Irurozqui, Marta. La ciudadanía en debate en América Latina. Discusiones historiográficas y una propuesta teórica sobre el valor público de la infracción electoral. Lima: Instituto de Estudios Peruanos, 2004.

Jiménez Hernández, Wilson. "El Papel Periódico Ilustrado y la configuración del proyecto de la Regeneración (1881-1888). Historia Crítica 47 (2012): 115-38.

Koselleck, Reinhart. Futuro pasado. Para una semántica de los tiempos históricos Barcelona: Ediciones Paidós Ibérica, 1993.

Loaiza Cano, Gilberto. Manuel Ancízar y su época. Biografía de un político hispanoamericano del siglo XIX. Medellín: Editorial Universidad de Antioquia, Facultad de Ciencias Humanas y Económicas de la Universidad Nacional de Colombia-sede Medellín, Fondo Editorial Universidad Eafit. 2004.

Loaiza Cano, Gilberto. Sociabilidad, religión y política en la definición de la nación. Colombia, 1820-1886. Bogotá: Universidad Externado de Colombia, 2011.

Múnera Ruiz, Leopoldo. "El Estado en la Regeneración. (¿La modernidad política paradójica o las paradojas de la modernidad política?)". La Regeneración revisitada. Pluriverso y hegemonía en la construcción del Estado-nación en Colombia. Leopoldo Múnera Ruiz, Edwin Cruz Rodríguez, eds. Bogotá: La Carreta Editores, 2011. 14-21.

Palacios, Marco. "La Regeneración ante el espejo liberal y su importancia en el siglo xx”. Miguel Antonio Caro y la cultura de su época. Rubén Sierra Mejía, ed. Bogotá: Universidad Nacional de Colombia, 2002. 261-78.

Palti, Elías. La nación como problema. Los historiadores y la "cuestión nacional". Buenos Aires: Fondo de Cultura Económica, 2002.

Papel Periódico Ilustrado. 1881-1888. Cinco tomos. Recopilados por su director Alberto Urdaneta.

Papel Periódico Ilustrado 1881-1888. Reproducción de los grabados en madera (xilografías) del Papel Periódico Ilustrado. Grabador Antonio Rodríguez y otros. Bogotá: Banco de la República, 1968.

Pérez, Amada Carolina. Nosotros y los otros. Las representaciones de la nación y sus habitantes. Colombia 1880-1910. Bogotá: Editorial Pontificia Universidad Javeriana, 2015.

Pocock, J. G. A. "The Ideal of Citizenship Since Classical Times". The Citizenship Debates. Gershon Shafir, ed. Minneapolis: U of Minnesota P, 1998. 31-41.

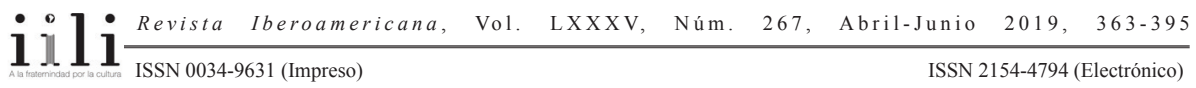


Posada Carbó, Eduardo. “¿Libertad, libertinaje, tiranía? La prensa bajo el Olimpo radical en Colombia, 1863-1885". El Radicalismo colombiano del siglo XIX. Rubén Sierra Mejía, ed. Bogotá: Universidad Nacional de Colombia. Facultad de Ciencias Humanas, 2006. 147-66.

Rausch, Jane. La educación durante el federalismo Bogotá: Instituto Caro y Cuervo y Universidad Pedagógica Nacional, 1993

Riall, Lucy. Garibaldi: Invention of a Hero. New Haven: Yale UP, 2007.

Sierra Mejía, Rubén, ed. Miguel Antonio Caro y la cultura de su época. Bogotá: Universidad Nacional de Colombia, 2002.

ed. El Radicalismo colombiano del siglo XIX. Bogotá: Universidad Nacional de Colombia, 2006.

Urrego Ardila, Miguel Ángel. "Régimen de verdad: estrategia de dominación en el período de la Regeneración". Hojas Universitarias. Revista de la Universidad Central IV/41 (1995): 103-28.

Vega Bendezú, Mauro. Discursos sobre "raza” y nación en Colombia: 1880-1930. Cali: Universidad del Valle, 2013.

Vergara y Velasco, Francisco Javier. Almanaque y guía ilustrada de Bogotá para el año de 1881. Bogotá: Imprenta de Ignacio Borda, 1881.

Zuleta Álvarez, Enrique. "Miguel Antonio Caro y la emancipación hispanoamericana". Thesaurus: Boletín del Instituto Caro y Cuervo 11/3 (1960): 515-50.

Palabras clave: Estado-nación, visualidad, modernización, regeneración, negación del Otro

Recibido: $\quad$ junio 2016

Aprobado: $\quad$ septiembre 2018

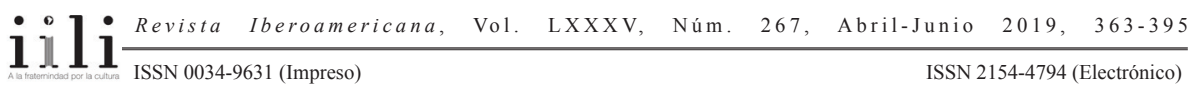


